\title{
Distribution, morphology and triggers of submarine mass wasting in the Sea of Marmara
}

\author{
T.A.C. Zitter ${ }^{a, *}$, C. Grall ${ }^{a, f}$, P. Henry ${ }^{a}$, M.S. Özeren ${ }^{b}$, M.N. Çağatay ${ }^{b}$, A.M.C. Şengör ${ }^{b, c}$, L. Gasperini ${ }^{d}$, \\ B. Mercier de Lépinay ${ }^{e}$, L. Géli $^{f}$
}

\author{
a Aix Marseille Université, CNRS, Collège de France, IRD, CEREGE UMR7330, 13545 Aix-en-Provence cedex 4, \\ France \\ ${ }^{\mathrm{b}}$ Istanbul Technical University, Department of Geology, Istanbul, Turkey \\ ${ }^{c}$ Istanbul Technical University, Eurasia Institute of Earth Sciences, Istanbul, Turkey \\ d ISMAR, Italy \\ e Géoazur, CNRS, Université de Nice, IRD, OCA, Nice, France \\ ${ }^{f}$ IFREMER, French Research Institute for Exploitation of the Sea, Brest, France
}

*: Corresponding author : T. A. C. Zitter, Tel.: + 33442381461 ; email address : zitter@atgeo.fr

\begin{abstract}
:
An overview is given of mass wasting features along the slopes of the Sea of Marmara, Turkey, based on new data and previously published information. The Sea of Marmara is characterized by active tectonics along the North Anatolian Fault and by eustatic sea level changes controlling the connections both to the Mediterranean and Black Sea (i.e. lacustrine and marine conditions during sea-level low and high stands, respectively). High resolution bathymetric data, subsurface echosounder and seismic reflection profiling, seafloor visual observations, as well as stratigraphic analysis of sediment cores have been used to identify, map and date submarine slope failures and mass wasting deposits. Gravity mass movements are widespread on the steep slopes of the Sea of Marmara, and range from small scale slope failures, mainly located within the canyons, to wider unstable areas $\left(20\right.$ to $\left.80 \mathrm{~km}^{2}\right)$. The largest mass wasting features, i.e. the Tuzla, Ganos and Yalova complexes, have been analyzed in connection with crustal deformation. These gravitational gliding masses are probably induced by the transtensional deformation within the crust. Moreover, age determination of landslides and debris flows indicate that they were more frequent during the last transgressive phase, when the rate of terrigenous sediments supplied by the canyons to the deep basin was higher. We discuss these results taking into account activity, pre-conditioning and trigger mechanisms for slope instability with respect to tectonics and paleo-environmental changes induced by sea-level oscillations.
\end{abstract}

\section{Highlights}

We map mass wasting features in the Sea of Marmara. Climate change appears as one of the factor triggering slope instability. The biggest slides occur in areas of high micro-seismic activity. Underlying crustal deformation influence the distribution of slope instability. 
Keywords: Sea of Marmara ; mass wasting ; seafloor morphology ; sea-level ; normal faulting

\section{Introduction}

Massive slope instabilities are very common on continental slopes. They control the seafloor morphology and have a substantial role in terms of natural hazards. Sediment mass wasting features are usually distinguished as instantaneous mass failures on the one hand (including rock avalanches, slides and slumps) and mass flows on the other hand, either cohesive (debris and mud flows) or non-cohesive (i.e. turbidity currents) (Coussot and Meunier, 1996 and Mulder and Cochonat, 1996). These distinctions reflect differences in the deformation processes, depending on the characteristics of the solid component and the water content. Although many types of mass movements are included in the general term "landslide", submarine slides, either translational or rotational, should be restricted to consolidated material sliding above a slip or "decollement" surface. Creep is a particular type of mass flow defined by a very slow gravity-driven downward motion of slope caused by shear deformation (Flood et al., 1993, Lee and Chough, 2001 and Lee et al., 2002). Creep is associated with sediment waves on the seafloor, although these can also be related to other processes such as contourite or turbidity-currents (Lee et al., 2002). All of these processes generally grade into one another during transport, so that they may occur sequentially during a single destabilization event.

Little is known about triggers of deepwater failures. However, numerous studies demonstrate that the importance and recurrence of mass wasting on continental slopes depend on multiple factors such as lithology, structural inheritance, seismicity, tectonic activity, sedimentary input, eustatism, or fluid overpressure (Piper et al., 1997, Orange et al., 1999, Hovland et al., 2001, Leynaud et al., 2004, 
Tripsanas et al., 2008; Mulder et al., 2009). Analysing mass wasting features morphology and occurrence patterns yields insight into the processes that shape a particular margin and other margins with similar settings.

Because the Sea of Marmara combines a high tectonic activity and drastic paleoenvironmental changes, it is a highly favorable environment for studying submarine mass movement triggers. The slopes of the Sea of Marmara, that have been intensively surveyed since the 1999 Izmit-Kocaeli earthquake, display numerous morphological signs of recent mass wasting processes (Gazioğlu et al., 2002; Görür and Çağatay, 2010; Özeren et al., 2010). This paper focuses on the various types of slope instabilities participating in the shaping of the Sea of Marmara basins. First, we will give an overview of the distribution, extent and timing of recent mass wasting features; then, based on the results of an analysis carried out over a number of different cases in different sectors of the Sea of Marmara, we will discuss the possible influence of tectonics and sea-level changes on triggering instabilities.

\section{Geological setting and previous studies}

\subsection{Structural and seismotectonic context}

The Sea of Marmara is located at a releasing bend along the single through-going westward prolongation of the North Anatolian Fault (NAF), the Main Marmara Fault (MMF, Le Pichon et al., 2001; Rangin et al., 2004). It comprises three main basins with rather steep slopes, from west to east respectively: the Tekirdağ, Central and Çınarcık Basin, separated by two major structural highs, the Western and Central Highs (Fig. 1). The MMF comprises more precisely three connected segments in the Sea of the Marmara: the Tekirdağ Basin/Western High segment, the Istanbul segment extending over the Central High, and the Çınarcık segments forming two major bends of the Main Marmara Fault (Grall et al., 2012; Seeber et al., 2006). The extensional component of motion is partitioned between oblique portions of the MMF and secondary fault branches (Şengör et al., 1985; Le Pichon et al., 2001; Armijo et al., 2002; Le Pichon et al., 2003; Şengör et al., 2005). The Ganos bend (Seeber et al., 2004) limits a western uplifted area, the Ganos Mountain, where thrusting is prominent 
particularly onland (Yaltirak, 2002; Seeber et al., 2004), on to a southeastern subsiding area, the Tekirdağ Basin. At the eastern end, two bends can be described at either ends of the Çınarcık Basin: the Tuzla bend and the Istanbul bend (Seeber et al., 2006). Historical earthquake activity in the Sea of Marmara region is organized in sequences with a typical recurrence of 200-300 years (Ambraseys and Finkel, 1995; Ambraseys and Jackson, 1998; Ambraseys and Jackson, 2000; Yalciner et al., 2002; Parsons, 2004). Numerous micro-seismic studies focus on the Tuzla bend along the northern Çınarcık fault segment (Karabulut et al., 2002; Karabulut et al., 2003; Sato et al., 2004; Örgülü, 2011; Karabulut et al., 2011). This area still retains microseismic activity after the 1999 Izmit-Kocaeli earthquake, consisting mainly of normal fault aftershocks (Karabulut, 2002). Focal mechanisms indicate shallow normal faulting ( 5 to $10 \mathrm{~km}$ deep) and deeper strike-slip faulting $(11-14 \mathrm{~km})$ (Karabulut et al., 2002).

Part of the extensional deformation is also accommodated by the South Transtensional Zone (STZ, Grall et al., 2012). This area comprises low-angle normal faults, that probably have been redistributing crustal stretching since the early stages of basin formation (i.e. 5-3.5 Ma) (Bécel et al., 2010; Grall et al., 2012). However, it is unclear whether these low angle faults are still active, except in the southern Central Basin where there is evidence of present day activity (Bécel et al., 2009; 2010).

\subsection{Marine/lacustrine transition within the Sea of Marmara}

The paleoceanographic history of the Sea of Marmara during the glacio-eustatic cycles exhibits several disconnections and reconnections with the Mediterranean Sea water circulation (Ryan et al., 1997; Aksu et al., 1999; Major et al., 2002; McHugh et al., 2008; Çağatay et al., 2000; 2009). The Holocene marine sedimentation is composed of homogeneous greenish silty mud and laminated sapropel containing coccoliths (notably Braarudosphera sp.) and benthic foraminifers typical of a low oxygen marine environment. During that period, sedimentation rates varied from 0.1 to $0.5 \mathrm{~m} / \mathrm{ka}$ on the plateau and shelves (Çağatay et al., 2000) to a maximum of $3 \mathrm{~m} / \mathrm{ka}$ in the deep basins (Stanley and Blanpied, 1980; Çağatay et al., 2000). The sedimentation rates may have been 2 to 3 times 
higher in the lacustrine period (Çağatay et al. 2003). During the last glacial, the Sea of Marmara was a brackish water lake (Aksu et al., 1999; Çağatay et al., 2000; Ryan et al., 2003; Zitter et al., 2008). The brackish lacustrine sedimentation in the deep basins is characterized by grayish laminated and banded sediments with locally dark reduced spots and pyrite. The fauna associated with the shallow lacustrine/brackish waters are fresh water bivalves (Dreissena sp.), diatoms (Stephanodiscus, Aulacoseira, Diploneis, Cyclobella), and ostracodes (Leptocythers, Candona Angulata adults and juveniles). The transition from lacustrine to marine deposits is marked by a peak in carbonate content (Reichel and Halbach, 2007; Vidal et al., 2010) and the presence of a sapropelic layers within the marine sediments (Çağatay et al., 1999; 2000). The most recent reconnection is dated at 14.7 cal. Ka BP (Vidal et al., 2010) and followed by a progressive transition towards marine conditions lasting more than 1.5 ka (Reichel and Halbach, 2007; Çağatay et al., 2009; Vidal et al., 2010).

\subsection{Morpho-sedimentary context}

Within the Sea of Marmara, the sediments are dominated by terrigeneous infill composed of $75 \%$ gravity-induced discrete events sedimentation (turbidites and mud/debris flow) intercalated with 25\% hemipelagic deposits (Beck et al., 2007, Çağatay et al., 2000; Çağatay et al., 2003, Çağatay et al., 2009). These events have been tentatively correlated with earthquakes or tsunamis (McHugh et al., 2006; Beck et al., 2007; Hébert et al., 2005; McHugh et al., 2008; Çağatay et al., 2009). It is inferred that the 1999 Izmit-Kocaeli earthquake, that produced a surface rupture reaching the western end of the Gulf of Izmit (Gasperini et al., 2011), triggered mass wasting events (Polonia et al., 2002; Kuşçu et al., 2005; Cagatay et al., in press). Within the Central Basin, Beck et al. (2007) identified a several meters thick homogeneous transparent acoustic layer, named "homogenite" (Kastens and Cita, 1981), and composed of very fined-grained sediment likely re-suspended after a large mass-wasting event, consequence of a tsunamigenic earthquake. This event that remobilized at least $0.6 \mathrm{~km}^{3}$ of sediment occurred ca. 15.5-16 cal. ka (Beck et al., 2007), pre-dating about 1 ka before the lacustrine to marine transition. 
130 Numerous studies of the seafloor morphology of the Sea of Marmara identified sediment waves

131 (Okay et al., 1999; Imren et al., 2001 and Shillington et al., 2012) and mass wasting features (e.g.

132 (Gazioğlu et al., 2002; Altinok et al., 2003; Gazioğlu et al., 2005; Gökçeoğlu et al., 2009; Görür and

133 Çağatay, 2010; Özeren et al., 2010). A large part of these studies focused on two main landslides: the

134 Ganos Complex (Gazioğlu et al., 2002; Altinok et al., 2003; Gazioğlu et al., 2005) and the Tuzla

135 Complex (Gazioğlu et al., 2002; Gazioğlu et al., 2005; Gökçeoğlu et al., 2009; Görür and Çağatay,

136 2010; Özeren et al., 2010).

137 The Tuzla Complex is located at the eastern end of the straight cliff bounding the Çınarcık Basin to

138 the north, where Paleozoic bedrock outcrops along the headwall of the scarp (Özeren et al., 2010).

139 According to the convexity of the upper part of the landslide and to the hummocky topography of

140 the landslide, Gökçeoğlu et al. (2009) assumed that the Tuzla Complex is a deep-seated rotational

141 landslide and proposed to relate it to the secondary NW-SE faults (Tur et al., 2007). One of the two

142 cores recovered in this area by Özeren et al. (2010) reached the top of the debris flow which is

143 composed of angular mudstone clasts within a sandy mud matrix, $60 \mathrm{~cm}$ below the marine/lacustrine

144 boundary. The age of this debris flow is estimated ca. 17ka BP but the geometry of the deep-seated

145 landslide beneath the sediments deposited in Çınarcık Basin suggests a much longer history spanning

146 at least one glacial cycle (Özeren et al., 2010). The Ganos Complex is located at the southwestern end

147 of the Tekirdag basin. The direction of sediment flow on the Ganos Complex has been investigated by

148 Gazioğlu et al. (2002) who proposed a single flow line, with an E or ENE orientation. The occurrence

149 of a detachment below the complex is suggested by the work of Okay et al. (1999).

150 Sediment wave fields occur in various places on the seafloor of the Sea of Marmara and have been

151 investigated by different authors (Okay et al., 1999; Imren et al., 2001; Shillington et al., 2012)

152 proposing different interpretations. More recently, a detailed analysis of these undulations, based on

153 high resolution seismic data, concluded that these sediment waves correspond to slow gravity-driven

154 downslope creep (Shilington et al., 2012). 


\section{Identification of mass wasting areas: data and methods}

157 This study integrates marine datasets acquired during several cruises in the Sea of Marmara. Morphological analysis is based on multibeam bathymetric and backscatter data. These data were acquired from R/V Le Suroit during the Marmara Cruise in 2000 using a $30 \mathrm{kHz}$ multibeam SIMRAD EM300 system for which a Digital Elevation Model (DEM) with $38 \mathrm{~m}$ grid resolution was generated. Shaded bathymetry and maps of slope gradient and slope aspect were automatically created using the ArcGIS spatial analyst tool. Average slopes were determined within polygonal areas defined by a

163

164 similar slope along the margins of the main basins and on major submarine landslides (Tab. 1). High resolution chirp profiling (with a hull-mounted $3.5 \mathrm{kHz}$ echosounder) was obtained during the Marmarascarps cruise in 2001 and the Marnaut cruise in 2007 on board R/V L'Atalante, and during Marmara VT in 2004 on board the R/V Marion Dufresne. Manned submersible dives took place during the Marnaut cruise (2007) with the submersible Nautile. Sediment cores were collected with different sampling devices: a Kullenberg corer with a 10-m-long barrel on R/V L'Atalante (designated with letters MNT) and with the giant Calypso piston corer on R/V Marion Dufresne (designated with letters MD). MD cores were cut in sections of $1.5 \mathrm{~m}$ and MNT cores in sections of $1 \mathrm{~m}$. X-ray radiographs of several cores were obtained with the SCOPIX system of Bordeaux University to reveal internal structures. Core MD042737 was also subsampled every $40 \mathrm{~cm}$, around the supposed depth of the marine/lacustrine transition (i.e. within the last 10 metres of the core), and these subsamples were sieved and smear slides were made. Nanno fossils and diatoms were studied on the smear slides. Other fossils were picked from the $150 \mu \mathrm{m}$ fraction.

Mass wasting features can be identified from high resolution bathymetry (McAdoo et al., 2000). Slides and slumps generally display sharp boundaries both upslope and downslope. They display concave-downslope scar failures, with a steep headwall scarp (Fig. 2a). Mass flows (debris flows, mud flows and turbidites) can be more difficult to identify in the bathymetric data when they lack clear distal toes (Loncke et al., 2009b). In this case, high resolution seismic profiling, such as $3.5 \mathrm{kHz}$ data, correlated with piston coring data is necessary to constrain the basinal extension of the features. On 

echo-sounder profiles, different echo-types can correspond to mass transport deposits (Fig. 2b). They are often recognised as acoustically transparent facies, in seismic profiles, corresponding to a homogeneous mud (homogenite) in cores. The homogenite is coupled with a basal coarse turbidite having a sharp and often erosive base (Beck et al., 2007; Çağatay et al., in press) (Fig. 2c). Hyperbolic, chaotic, and hummocky echo-characteristics can also correspond to deposits generated by mass wasting processes (Damuth, 1980; Embley, 1980; Loncke et al., 2006; Loncke et al., 2009a; Loncke et al., 2009b). Well-stratified continuous and parallel reflections that usually characterize pelagic and hemipelagic sediments may also correspond to cyclic deposition by turbidity currents (Domzig et al., 2009, Fig. 11 in Zitter et al. 2008). Proximal mass wasting features can display different lithologic facies within cores (Fig. 2c) such as mixed sand and shell debris layers, lenses, and lithified or semilithified mud pebbles (Embley, 1980).

\section{Results}

\subsection{Morphology and distribution of mass wasting features}

The slopes of the northern margin of the Sea of Marmara are generally steeper and less sedimented than the southern ones (Fig. 3 and Tab. 1). The steepest slopes are located on the north-western side of Tekirdağ Basin (Ganos slope) where the average gradient is $19^{\circ}$ (Tab. 1), and on the northern and southeastern sides of Çınarcık Basin, with $23^{\circ}$ and $17^{\circ}$ average gradients respectively. The Central Basin exhibits slope gradients of $8^{\circ}$ on average in the south and $11^{\circ}$ in the north, and the southern and northern sides of Tekirdağ Basin have slope gradients of $8^{\circ}$ on average (Tab. 1).

Figure 3 presents a map of morphological evidence of slope instabilities and the network of canyons in the Sea of Marmara. All submarine mass wasting features identified on the seafloor of the Sea of Marmara in this study are also presented in Table 2 together with references to previous studies.

Slope instabilities are more common along the southern margin. Individual zones of instability range from 0.5 to more than $100 \mathrm{~km}^{2}$ in surface area (Tab. 2). The smallest features are associated with 

steep canyon walls. The largest are observed along both flanks of the Çınarcık Basin and on the southern slopes of the Tekirdağ and Central Basins. The Central and the Western Highs both exhibit slope instabilities. Many relatively small-scale arcuate scars are observed in the Western High. On the Central High slopes facing both the Çınarcık Basin and the Kumburgaz Basin, two broad zones (features 24 and 25 on Fig. 3) are affected by regularly spaced steps. Within the Tekirdağ Basin, the majority of submarine mass wasting features are located along the southern sedimented slope (features 1 to 6 ) despite the northwestern edge being much steeper. The Central Basin exhibits smaller and fewer mass wasting and most of them are located on its southwestern side, in association with the more developed canyon pattern, and at the toe of the Western High (features 11 to 21 ). Only one landslide (feature $22 ; 24 \mathrm{~km}^{2}$ in area) is observed in the northeastern part of the basin. Both northern and southern slopes of the Çınarcık flanks are affected by slope instabilities but the area they cover is wider in the south.

\subsection{Characterisation of mass wasting features}

\subsection{1.Çınarcık Basin}

The Tuzla Landslide Complex (feature 30 on Fig. 3, Fig. 4) exhibits a large curvilinear slope failure, 32 $\mathrm{km}^{2}$ in area, with an amphiteatre-like shape. It can be divided into two distinct areas. The western part displays a well-defined headwall scarp on the upper slope with a total height drop of 250 to 300 m (Fig. 5) and an average slope of $21^{\circ}$ (Tab. 1). Several linear features, and smaller scarps, are visible within the bathymetry in the western part of the landslide. Rotated blocks are seen in the seismic section (Fig. 5) down slope up to $3000 \mathrm{~m}$ away from the main scarp. This part of the slope failure should thus be classified as a rotational slide, although it is unclear whether it resulted from a single event. Seismic profiles (see Fig. 5) show that at least $250 \mathrm{~m}$ of sediments within the basin onlap the top of the main slide body. Even for a maximum sedimentation rate estimated at $7 \mathrm{~mm} / \mathrm{yr}$ during the last glacial time (Seeber et al., 2006), this would correspond to a minimum age of 35000 years. 

at $1100 \mathrm{~m}$ of water depth, implying that the slide affects the Palaeozoic basement of the Istanbul block and suggesting sliding surfaces may root in these black shales. The eastern part of the feature, separated by a NNE-SSW trending ridge, already described by Tur et al. (2007), consists of a rough seafloor, with an average slope of $14^{\circ}$. It exhibits small normal faults and erosional gullies. Although less steep than the northern Çınarcık slope, the southern Çınarcık slope with an average slope of $11^{\circ}$ is also affected by numerous instabilities (Fig. 4). The easternmost part of the slope exhibits the highest slope angle (around $17^{\circ}$ ); and a landslide complex of $21 \mathrm{~km}^{2}$, hereafter called the Yalova Complex, affects the entire slope from the shelf break to the basin (feature 29 on Fig. 3, Fig. 6). Concave downslope crescent shaped scars and debris flows are recognizable upslope, as well as a rectilinear headwall scarp. Numerous erosional gullies are observed from the scarp down to the basin. The Yalova Complex is cut by left-lateral faults, oriented N340 (parallel to the slope direction) that displace the base of the slope stepwise (Fig. 6). The toe of the landslide was explored during a submersible dive: it shows an accumulation of blocks of various sizes as well as evidence for fluid expulsion. Broken pieces of authigenic carbonate crusts observed on the seafloor were up to $15 \mathrm{~m}$ high, associated with fluid seepages. Alignments of 3-4 m long black patches of reduced sediments, striking $\mathrm{N} 310^{\circ}$ in the slope direction, are seen in some places and appear to coincide with the location of the left lateral faults (Fig. 6). In this part of the slope there are also several recent small rock debris accumulations from rock avalanches that are not yet covered by hemipelagic sediments. Between $\mathrm{E} 28^{\circ} 50$ and $\mathrm{E} 29^{\circ} 10$, the slope is affected by faults, perpendicular to the slope direction, deep-seated transtensional shear zone, and the deformation of the seafloor may result from a combination of slope failure and tectonic motion. In this latter case, the faults observed on the bathymetry probably correspond to en-échelon normal faults induced by the transtensional deformation (Géli et al., 2008). Along the northern toe of the Çınarcık slope, at the base of a steep 
cliff of Palaeozoic sediments, fallen blocks varying sizes from tens of centimetres to metre size boulders and slabs are commonly observed to be covered by a 1 to $10 \mathrm{~cm}$ sediment blanket (Fig. 7).

\subsubsection{Western High and Central Basin}

At the toe of the eastern slope of the Western High, in the Central Basin, some acoustically transparent lenses are seen directly at the seafloor indicating recent deposition. A Nautile dive in this area found a layer of authigenic carbonate crusts that was outcropping locally at a water depth of $1200 \mathrm{~m}$ on a very steep slope. This observation indicates that sliding occurred, exhuming carbonate crusts formed by fluid seepage activity either within the sediments or at seafloor.

Mass wasting deposits were found also in cores MNTKS19 and MNTKS22 located in the NE corner of the Central Basin at the toe of a landslide (feature 22 on Fig. 3). Core MNTKS19 shows at $205 \mathrm{~cm}$ depth a $35 \mathrm{~cm}$ thick section of very fine sand with shell debris which could correspond to the distal part of a mass flow. At a depth of $230 \mathrm{~cm}$, in core MNTKS22, a $40 \mathrm{~cm}$-thick interval was found with mud clast, pebbles and deformed sandy lenses, possibly corresponding to the same event.

\subsubsection{Tekirdağ Basin}

The Ganos Complex is located at the eastern end of the Ganos fault rupture over an elliptical area of $85 \mathrm{~km}^{2}$ (feature 1 on Fig. 3, Fig. 8). This feature, which extends from a water depth of $150 \mathrm{~m}$ to 1100 $\mathrm{m}$, shows a complex morphology. The slope, with an average gradient of $5^{\circ}$, is affected by small steplike scarps and sediment waves, perpendicular to the slope dip, and presents a rough and hummocky topography. Chirp profile Marnaut 16, running across the slope, shows an acoustic facies characterized by regular hyperbolae (Fig. 8). Along the northern side of this large moving mass, several imbricated crescent-shaped scars (features 3 and 4 on Fig. 3 ) indicate multiple smaller scale events of gravity sliding in retrogressive sequence. These slope failures are located along the strikeslip fault trace, where the transpressional fault that lies along the base of the Ganos slope branches off the main strike-slip fault lying along the southern slope of the Tekirdağ Basin (Fig. 8). An arcuate 
shaped scar and irregularities in the bathymetry suggest a debris flow occurred in the upper part of the slope (feature 2 on Fig. 3). Retrogressive slope failures can also be observed at the toe of the landslide complex.

Cores MD042737, MD042740 and MNTKS30, located at the mouth of a canyon in the Tekirdağ Basin (see core location in Fig. 9), contain several silty-turbidite sequences, coarse shelly sand layers, and thick sandy or muddy layers with clay pebbles and mud clasts interpreted as a debris flow (Fig. 10). This debris flow facies is found at depths varying between 200 and $600 \mathrm{~cm}$ (Fig. 10). Considering the average sedimentation since the lacustrine to marine transition in the cores, the debris flow may correspond to a single event that occurred during the Holocene marine episode, but could not be precisely dated. Several deeper coarser sand beds with abundant Dreissena sp. shells are observed within the cores MD042737 and MD042740. In core MD042737, the marine-lacustrine transition is deduced from observations of micro and nanno fossils (foraminifera, ostracodes, diatoms) with progressive salinization of the waters between 31.75 and $30.5 \mathrm{~m}$ (this depth has been corrected for gas expansion on the basis of observed holes/gaps in the core), corresponding to an average sedimentation rate of $2.5 \mathrm{~m} / \mathrm{ka}$ during the marine period, including mass wasting deposits. Sediment cores have been correlated with $3.5 \mathrm{kHz}$ echosounder data (Fig. 11). Strong reflections correspond to turbidite sequences containing multiple sand laminae, and to the top of a thick coarse shelly sand layer at the base of the core (around $30 \mathrm{~m}$ depth below seafloor at the MD042737 location, i.e. 0.4s twt, Fig. 11). Reflections within the lacustrine facies tend to be fuzzy, in contrast to the marine sedimentary sequence that exhibits a well layered acoustic facies (Fig. 11).

A buried transparent lens interbedded within the hemipelagic sediments and the turbidites could be distinguished in several $3.5 \mathrm{kHz}$ echo-sounder profiles running across the toe of the slope on the SE flank of the Tekirdağ Basin (Fig. 2b, 8 and 10). According to its location, this mass wasting deposit could be related to an arcuate shaped slope failure observed on the NW side of the western High (Fig. 2a and feature 8 in Fig. 3). Following the marine/lacustrine transition depth to the west, we can observe that the transparent lens is located just on top of the strong reflector corresponding to the 
coarse shelly sand bed. Thus, this large debris flow occurred during the lacustrine to marine

311 transition or shortly afterwards (ca. 14 cal. Ka BP).

\subsection{The canyon network: erosional features}

314

We observed numerous canyons and erosional gullies cutting across the slopes and some of the structural highs, with direct pathways to the deep basins. Most canyons and their tributaries originate near the continental-shelf break and extend to the base of the continental slope. They usually have high reflectivity in the EM300 multibeam backscatter images (Fig. 1) potentially caused by the slope incision, the presence of coarse and/or heterogeneous material in the bottom of the thalweg or the increased seafloor roughness from erosion within the canyon (e.g. (Augustin et al., 1996; Kenyon et al., 2002; Lamarche et al., 2011). We observed areas within canyons with both relatively high backscatter (both flanks of the Central basin and southern flank of the Tekirdağ Basin) and lower backscatter (north of the Tekirdağ Basin and Çınarcık Basin) that may indicate differences in recent activity or in the nature of the sediments. Along the steepest slopes (NW Tekirdağ, NE and S Çınarcık) the canyons are straight, narrow (a few hundred meters wide) and short (1 to $2 \mathrm{~km}$ long). No levees are associated with these canyons suggesting that they are dominated by erosion. On gentler slopes (S Tekirdağ Basin and Central Basin), canyons are longer (up to $15 \mathrm{~km}$ ), wider (1 to 3 $\mathrm{km}$ ), and incise deeper (100 to $400 \mathrm{~m}$ ). Steeper slopes are found at the head of the canyons (20 to $\left.30^{\circ}\right)$ and along the flanks $\left(10\right.$ to $\left.20^{\circ}\right)$, whereas the bottom of the thalweg has 1 to $3^{\circ}$ slopes. The channels have several branches that are often deflected, especially in the proximity of the major topographic highs. Meandering channels are exceptional. One such channel is observed flowing northward of Imralı Island towards the Central Basin ending in the Çınarcık Basin (Fig. 1), which constitute the submarine extension of the Kocasu. Arcuate submarine slide scars, observed on the walls of the canyons (Fig. 3 and 9), and scours in the bottom of the thalweg, indicate that erosion within the canyons contribute to the sediment input to the basins (Fig. 9). Canyon wall instability is observed, notably within the canyons located south of the Central Basin, on the southern side of the 

of the slope. Acoustically transparent lens shaped bodies with $8 \mathrm{~m}$ maximum thickness are found in both canyons that are interpreted as debris flow deposits. On top of these bodies, stratified hemipelagic sediments reach $5 \mathrm{~m}$ thickness in the western canyon and pinch out towards east. These observations indicate a decrease in the activity of the canyons after the deposition of the debris flow (Fig. 9); a conclusion also supported by the generally flat floor of canyons thalwegs, particularly at their mouths, which contrasts with the morphology of presently more active canyons.

\section{Discussion}

\subsection{Influence of paleoenvironmental changes on mass wasting processes}

347 Sea-level oscillation modulates the sediment supply and consequently the activation of gravity mass movements. Near the end of the lacustrine period, coarse shelly sand was transiting the shelf to the deep basin through the canyons. During the marine period, turbidite layers appear thinner and finer grained and a part of the sediment transfer occurs by muddy debris flow. Several authors (Beck et al., 2007; McHugh et al., 2008; Çağatay et al., 2009) also note that gravity flows such as turbidity currents were more frequent during the lacustrine stage than during the marine stage. Furthermore, seismoturbidites are more frequent during the lacustrine period, although this is unlikely to reflect a variation in seismic activity (McHugh et al., 2008).

The dating of mass wasting deposits indicates that the large mass wasting events occurred more frequently at the end of the last glacial period (12-17 ka). For example, the homogenite in the Central Basin is dated around 15.5-16 ka (Beck et al., 2007), and a mudflow on the larger Tuzla Complex is dated 17 ka by Özeren et al. (2010). However, this landslide complex appears to be a multi-event feature and older mass wasting deposits (probably as old as $35 \mathrm{ka}$ ) have been identified within the seismic section. By correlating the sedimentary facies and the different seismic horizons within the chirp profile in the Tekirdağ basin (Fig. 11), we have estimated that a large debris flow was deposited 
during the lacustrine to marine transition or shortly afterwards (ca. 14 cal ka BP) (Fig. 9 and 11). We also presented evidence here for variations in canyon activity for the case of the southern slope of Tekirdağ Basin.

The observation of a $-85 \mathrm{~m}$ paleoshoreline, notably on the northwestern part of the Izmit Gulf (Çağatay et al., 2003), suggests that a large part of the present day shelves were exposed during the last glaciation when the Sea of Marmara was disconnected from the Aegean Sea. During this low stand, sedimentation rates were up to three times higher in the basins (Çağatay et al., 2000; Seeber et al., 2006). We documented that the canyons were transferring coarse sandy material at that time. It can be inferred that they were actively eroding and incising their own channels. The rapid sea-level rise at the end of the last glaciation resulted in temporary sediment storage on the shelves and a sudden decrease of sediment transfer through canyons by turbidity currents. The instability of the recently incised canyon slopes caused debris flows, which still remain visible buried within several canyons (Fig. 9). Afterward, sediment transfer by turbidity currents resumed, but with smaller fluxes. We cannot rule out that gas hydrate dissociation as a consequence of warming during deglaciation may have contributed to destabilization processes on the slope of the Sea of Marmara. Fluid ascent is often thought to be the cause of sediment destabilization (Hovland et al., 2001; Mienert et al., 2005). Numerous sites of fluid escape have been observed on the seafloor along the active fault traces in the Sea of Marmara (Halbach et al., 2000; Armijo et al., 2005; Géli et al., 2008; Zitter et al., 2008; Tryon et al., 2010) and gas hydrates were recovered within the subsurface sediments of the Western High (Bourry et al., 2009). In this area, massive methane release occurred in the watercolumn around 11 cal. ka BP, after the lacustrine to marine transition (Menot and Bard, 2010). However, it is yet unclear whether this event was associated with an increase of slope instability.

\subsection{Influence of underlying crustal deformation on mass wasting processes}

The deep structure beneath the large landslides is not well resolved but the distribution of microseismic activity (Sato et al., 2004; Karabulut et al., 2002; 2003; 2011; Örgülü, 2011) indicates active 
crustal strain is occurring beneath these landslides. We argue that the slope instabilities observed at a shallow level in the crust or within the sedimentary layers could be influenced by underlying crustal deformation, as has also been proposed in the case of deep seated gravitational slope deformation on land (e.g., Guglielmi and Cappa, 2009; Sanchez et al., 2010). Occurrence of large earthquakes on major faults is an obvious trigger of instability, but distributed strain and fracturing could also contribute to weaken the material above, eventually leading to catastrophic failure.

\subsubsection{The Tuzla Landslide}

Micro-seismic events in the Tuzla landslide area are oriented along two major trends: NE-SW and ESE-WNW (Fig. 12). It is interesting to note that the NE-SW alignment coincides with the northwestern slope failure of the landslide (Karabulut et al., 2002; Sato et al., 2004; Karabulut et al., 2011), but that strike of the nodal planes of the dominantly normal focal mechanisms is NW-SE (Fig. 12), (Fig. 4 in Karabulut et al., 2002), implying en echelon faulting in agreement with the expected pattern of faulting related to the northern branch of the North Anatolian Fault here, and with the dominant morphological grain on the Thracian isthmus (Şengör, 2011). Within the Tuzla landslide, several linear structures visible in the bathymetry also appear to coincide with alignments of micro-seismicity, as far as the accuracy of micro-seismic event localization permits. The Tuzla micro-seismic cluster is focused on the western triangular part of the Tuzla landslide, which is controlled by normal faulting, whereas fewer seismic events occur eastward (Fig. 12). This suggests that the occurrence and geometry of the landslide are controlled by active crustal structures.

\subsubsection{The SE Çınarcık landslides: the Yalova Complex}

Long term micro-seismic activity is present in a broader swath along the southern edge of Çınarcık Basin, where numerous slope instabilities are observed (features 27, 29, 31, 32 on Fig. 3) and at the entrance of the Izmit Gulf (Fig. 12). This area in particular displays a large mass of creeping sediments (feature 32 on Fig. 3) extending over $12 \mathrm{~km}^{2}$ and partially covering the fault trace near the end of the 1999 Izmit-Kocaeli earthquake rupture and the Yalova Complex (Fig. 6), (Gasperini et al., 2011). Unsedimented chaotic blocks and associated active fluid seepages observed on the Yalova Complex, 

the northern shore of the Armutlu Peninsula (Parke et al., 1999; Armijo et al., 2002; Parke et al., 2002). This fault segment shows important micro-seismic activity, particularly in the vicinity of cities of Çınarcık and Yalova, with transtensional focal mechanisms (Fig. 4 in Karabulut et al., 2002; Sato et al., 2004; Karabulut et al. 2011, Örgülü, 2011). The northwestward gliding motion of the Yalova Complex may relate to the transtensional deformation, associated with the Armutlu fault.

\subsubsection{The Ganos Landslide Complex}

421

Micro-seismic activity is found on the Ganos fault, and along both the southern and NE margins of the Tekirdağ Basin (Örgülü, 2011; Tary et al., 2011). The instrumental seismicity data show microseismicity beneath the Ganos Complex area, for the time-period between 1986 and 1996 (Gürbüz et al., 2000), 1996 and 2000 (Sato et al., 2004; Örgülü, 2011), 2002 and 2006 (Örgülü, 2011). The recurrence of the micro-seismicity in this area suggests some kind of relationship between the creeping of the Ganos Complex and tectonic strain in the crust (Fig. 12). The focal mechanisms below the Ganos complex (see Fig. 11 in Örgülü, 2011) are normal and strike slip with a consistent NE-SW direction of extension and, on a cross-section cut along this NE-SW direction appear to deepen northeastward from a very shallow depth at the edge of the complex to 10-15 km depth (Fig. 11 in Örgülü, 2011). This seismic activity could be related to sliding on a crustal detachment fault, dipping to the northeast beneath the Ganos Complex, and of comparable strike, dip and depth range as crustal detachments observed further east in multichannel data (Bécel et al., 2009; Grall et al., 2012).

The Ganos Landslide Complex generally slopes north-northeast (Fig. 8) and could indicate a global NE motion of the slide. We suspect a relationship between distributed transtensional deformation in the crust with shallow spreading and slope failure above.

Moreover, the Ganos Landslide Complex can be divided into two parts (Fig. 8): the southern part has a northeast trending slope averaging $5.6^{\circ}$; and the northern part has a steeper $9^{\circ}$ northward trending slope. The boundary between the two-sub-landslides corresponds to the linear prolongation of the Ganos fault segment of the NAF (Fig. 8) where micro-seismicity with strike-slip focal mechanism is 
441 Tekirdağ Basin is visible in the bathymetric data as a narrow furrow joining several mini-basins, 442 where mass transport deposits have been recognised from cores and chirp profiling (McHugh et al., 2006). The deposition of mass transport deposits and homogenites has been related to an earthquake, presumably the 1912 Ganos earthquake (McHugh et al., 2006). Further east, within the Ganos Landslide Complex, the furrow marking the fault ends within an arcuate slump scar (Fig. 3, features 3 and 4). Down slope, in the prolongation of the fault segment, the bathymetry is marked by

447 sigmoid waves, typical of dextral strike-slip deformation. These observations indicate that the Ganos 448 Landslide Complex is underlain by a blind segment of the NAF. Moreover, the fault bend is smoother 449 in the basin than previously proposed because the Ganos Landslide Complex obscures the trace of 450 the fault (Okay et al., 2004). As a consequence, the strike-slip motion is probably distributed between 451 the NW front and the bulk of the creeping sedimentary mass. The deformation associated with the 452 NAF may be responsible for the destabilization of the NW slope where numerous slumps and slide 453 scars are observed.

\section{$454 \quad$ 5.2.4. Role of transtensional deformation}

455 The location of large unstable slopes (i.e. Ganos, Tuzla and Yalova complexes), above seismically 456 active transtensional structures suggest a relationship between crustal transtension and the 457 observed deformation at the seafloor. However, most of the micro-earthquake hypocenters in these 458 areas are located at a deeper level (5 $\mathrm{km}$ on average, with a 1-10 $\mathrm{km}$ range) than the slope 459 instabilities, as the suspected sliding surfaces are never deeper than $1.5 \mathrm{~km}$ (Yaltirak, 2002; Rangin et 460 al., 2004) and often much shallower (see seismic profile Fig. 5). We propose that the component of 461 stretching imposed by crustal deformation promotes tensional fracturing of the rock mass leading to 462 failure of the overlying sediments. This type of relationship has been demonstrated on land where 463 long lasting and diffuse deformation coexists with volumetrically smaller but sometimes catastrophic 464 failure events (Brückl et al. 2005; Guglielmi and Cappa, 2009; Sanchez et al., 2010). In the Sea of 465 Marmara, the tectonic stress field can induce both strain softening and topography, and promote 
long lasting deep seated gravitational slope deformation which in turn promotes occasional short-

467 lasting and shallower mass movements. As a result, slopes adjacent to releasing bends or within transtensional areas may be more prone to slope failure than those near segments where the deformation is almost pure strike-slip and concentrated in a narrow fault zone.

\section{Conclusion}

472 Mapping mass wasting features in the Sea of Marmara demonstrates the widespread occurrence of slope instabilities. The Sea of Marmara indeed presents favorable conditions for submarine mass movement, with high sedimentation rates, dominated by silico-clastic deposits, drastic paleoenvironemental changes (marine/lacustrine conditions) caused by global sea-level oscillations enhanced by a peculiar physiography (the Dardanelles and the Bosphorous sills), and active tectonic

477 deformations maintaining very steep slopes ranging from 4 to $24^{\circ}$ on average.

478 Submarine mass movements are observed along about $30 \%$ of these slopes over a total area of more 479 than $500 \mathrm{~km}^{2}$. A diversity of mass wasting processes occurs as mainly landslides, mass flows and creep. We can distinguish gravity slides related to erosional processes within the canyons, initiated from the head walls and the incised channels of the canyons from wider unstable slopes that appear associated with transtensional crustal deformation evidenced from microseismicity. These unstable slopes display creeping down slope motion component, with a direction of motion coincident with the underlying crustal stretching. The stretching of the crust probably promotes strain softening within the shallow crust and sedimentary cover and large scale deep seated gravitational slope deformation. On the other hand, the vertical component of slip along the main faults contributes to steepen the slopes and consequently favors slope instability. This combination of factors may account for the observed concentration of large landslides near fault bends.

489 Cyclic sea level variations also influence the mass wasting processes. Several mass wasting deposits 490 observed in the sedimentary record appear to date back 11-17ka BP, i.e. corresponding to the end of 491 the lacustrine period and the early marine period. Morphological observations and high resolution 
492

493

494

495

496

497

498

499

500

501

502

503

504

505

506

507

508

509

510

511

512

513

514

515

516

profiling of the canyons also indicate variations in the rate of sediment transfer processes over the same time interval.

This study highlights that landslide triggering is dependent on contextual factors that influence the probability of occurrence of slope instabilities in space and time, for instance, the distribution of crustal stress and strain, paleo-environmental conditions and sea-level change.

\section{Acknowledgments}

We acknowledge the Captain, crew and technical staff of IFREMER-Genavir's R/V L'Atalante and of submersible Nautile, as well as the onboard scientific party, for their involvement during the Marnaut cruise. We also acknowledge the very efficient help of the Turkish Navy during this cruise. Financial support was provided by the "Agence Nationale de la Recherche" (project ISIS-ANR05-Catt005-01) and we thank Nabil Sultan who led the ISIS program. This work was carried out within the framework of the European Seas Observatory Network of Excellence (ESONET NoE) funded through the European Commission's Sixth Framework Programme under the priority 'sustainable Development; Global Change and Ecosystems'. We acknowledge Jean-Luc Schneider, Brice Ferger and Joël Saint-Paul (University of Bordeaux) for their work on SCOPIX measurements. We thank Luc Beaufort, Christine Pailles, Laetitia Licari, and Hélène Bruneton (CEREGE) for their help identifying biomarkers in the Sea of Marmara sediments. AMC Şengör records his gratitude to the Turkish Academy of Sciences for support. We thank John Woodside for his help on improving the English writing of this manuscript. We thank two anonymous reviewers for their constructive comments that improved this manuscript.

\section{References}


Aksu, A.E., Hiscott, R.N.,Yasar, D., 1999. Oscillating Quaternary water levels of the Marmara Sea and vigorous outflow into the Aegean Sea from the Marmara Sea Black Sea drainage corridor. Marine Geology, 153(1-4), 275-302.

Altinok, Y., Alpar, B.,Yaltirak, C., 2003. Sarkoy-Murefte 1912 Earthquake's Tsunami, extension of the associated faulting in the Marmara Sea, Turkey. Journal of Seismology, 7(3), 329-346.

Ambraseys, N., N.,Finkel, C.F., 1995. The seismicity of Turkey and adjacent areas, a historical review, 1500-1800. Eren, Istanbul, 240 pp.

Ambraseys, N.N.,Jackson, J.A., 1998. Faulting associated with historical and recent earthquakes in the Eastern Mediterranean region. Geophys. J. Int., 133, 390-406.

Ambraseys, N.N.,Jackson, J.A., 2000. Seismicity of the Sea of Marmara (Turkey) since 1509. Geophys. J. Int., 141, F1-F6.

Armijo, R., Meyer, B., Navarro, S.,King, G., 2002. Asymetric slip partitioning in the Sea of Marmara pull-apart : a clue to propagation processes of the North Anatolian Fault? Terra Nova, 13, 8086.

Armijo, R., Pondard, N., Meyer, B., Uçarkuş, G., de Lépinay, B.M., Malavieille, J., Dominguez, S., Gutscher, M.A., Schmidt, S., Beck, C., Çağatay, N., Cakir, Z., Imren, C., Eris, K., Natalin, B., Ozalaybey, S., Tolun, L., Lefevre, I., Seeber, L., Gasperini, L., Rangin, C., Emre, O.,Sarikavak, K., 2005.Submarine fault scarps in the Sea of Marmara pull-apart (North Anatolian Fault): Implications for seismic hazard in Istanbul. Geochemistry, Geophysics and Geosystemes, 6, Q06009, doi:10.1029/2004GC000896.

Augustin, J.M., LeSuave, R., Lurton, X., Voisset, M., Dugelay, S.,Satra, C., 1996. Contribution of the multibeam acoustic imagery to the exploration of the sea-bottom. Marine Geophysical Researches, 18(2-4), 459-486.

Bécel, A., Laigle, M., de Voogd, B., Hirn, A., Taymaz, T., Galve, A., Shimamura, H., Murai, Y., Lepine, J.C., Sapin, M.,Ozalaybey, S., 2009. Moho, crustal architecture and deep deformation under 
the North Marmara Trough, from the SEISMARMARA Leg 1 offshore-onshore reflectionrefraction survey. Tectonophysics, 467(1-4), 1-21, doi:10.1016/j.tecto.2008.10.022.

Bécel, A., Laigle, M., de Voogd, B., Hirn, A., Taymaz,T., Yolsal-Cevikbilen, S., Shimamura, H., 2010. North Marmara Trough architecture of basin infill, basement and faults, from PSDM reflection and OBS refraction seismics. Tectonophysics, 490, 1-2, 1-14, doi: 10.1016/j.tecto.2010.04.004.

Beck, C., Mercier de Lépinay, B., Schneider, J.L., Cremer, M., Çağatay, N., Wendenbaum, E., Boutareaud, S., Menot, G., Schmidt, S., Weber, O., Eris, K., Armijo, R., Meyer, B., Pondard, N.,Gutscher, M.A., 2007. Late Quaternary co-seismic sedimentation in the Sea of Marmara's deep basins. Sedimentary Geology, 199(1-2), 65-89, doi: 10.1016/j.sedgeo.2006.12.031.

Bourry, C., Chazallon, B., Charlou, J.L., Donval, J.P., Ruffine, L., Henry, P., Géli, L., Çağatay, M.N., Inan, S.,Moreau, M., 2009. Free gas and gas hydrates from the Sea of Marmara, Turkey Chemical and structural characterization. Chemical Geology, 264(1-4), 197-206, doi: 10.1016/j.chemgeo.2009.03.007.

Brückl, E.,Parotidis, M., 2005. Prediction of slope instabilities due to deep-seated gravitational creep. Natural Hazards and Earth System Sciences, 5(2), 155-172.

Çağatay, M.N., Algan, O., Sakinc, M., Eastoe, C.J., Egesel, L., Balkis, N., Ongan, D.,Caner, H., 1999. A mid-late Holocene sapropelic sediment unit from the southern Marmara sea shelf and its palaeoceanographic significance. Quaternary Science Reviews, 18(4-5), 531-540.

Çağatay, M.N., Eris, K., Ryan, W.B.F., Sancar, U., Polonia, A., Akcer, S., Biltekin, D., Gasperini, L., Görür, N., Lericolais, G.,Bard, E., 2009. Late Pleistocene-Holocene evolution of the northern shelf of the Sea of Marmara. Marine Geology, 265(3-4), 87-100, doi: 10.1016/j.margeo.2009.06.011.

Çağatay, M.N., Görür, N., Algan, O., Eastoe, C., Tchapalyga, A., Ongan, D., Kuhn, T.,Kuşçu, I., 2000. Late Glacial-Holocene palaeoceanography of the Sea of Marmara: timing of connections with the Mediterranean and the Black Seas. Marine Geology, 167(3-4), 191-206. 
Çağatay, M.N., Görür, N., Polonia, A., Demirbag, E., Sakinc, M., Cormier, M.H., Capotondi, L., McHugh, C., Emre, O.,Eris, K., 2003. Sea-level changes and depositional environments in the Izmit Gulf, eastern Marmara Sea, during the late glacial-Holocene period. Marine Geology, 202(3-4), 159-173.

Çagatay, M.N., Erel.,L., Belucci, L.G., Polonia, A., Gasperini, L., Eris, E., Sancar, U., Biltekin, D., Ucarkus, G., Ulgen, U.B., Damci, E. Sedimentary earthquake records in the Izmit Gulf, Sea of Marmara, Turkey. Sedimentary Geology (in press).

Coussot, P.,Meunier, M., 1996. Recognition, classification and mechanical description of debris flows. Earth-Science Reviews, 40(3-4), 209-227, doi:10.1016/0012-8252(95)00065-8.

Damuth, J.E., 1980. Use of high-frequency $(3.5-12 \mathrm{kHz})$ echograms in the study of near-bottom sedimentation processes in the deep-sea: A review. Marine Geology, 38(1-3), 51-75.

Domzig, A., Gaullier, V., Giresse, P., Pauc, H., Deverchere, J.,Yelles, K., 2009. Deposition processes from echo-character mapping along the western Algerian margin (Oran-Tenes), Western Mediterranean. Marine and Petroleum Geology, 26(5), 673-694, doi: 10.1016/j.marpetgeo.2008.05.006.

Embley, R.W., 1980. The role of mass transport in the distribution and character of deep-ocean sediments with special reference to the North Atlantic. Marine Geology, 38(1-3), 23-50.

Flood, R.D., Shor, A.N.,Manley, P.L., 1993. Morphology of Abyssal Mudwaves at Project Mudwaves Sites In The Argentine Basin. Deep-Sea Research Part II-Topical Studies in Oceanography, 40(4-5), 859-888, doi:10.1016/0967-0645(93)90038.

Gasperini, L., Polonia, A., Bortoluzzi, G., Henry, P., Le Pichon, X., Tryon, M., Cagatay, N.,Geli, L., 2011a. How far did the surface rupture of the 1999 Izmit earthquake reach in Sea of Marmara? Tectonics, 30, 11, doi:Tc10.1010.1029/2010tc002726.

Gazioğlu, C., Gokasan, E., Algan, O., Yucel, Z., Tok, B.,Dogan, E., 2002. Morphologic features of the Marmara Sea from multi-beam data. Marine Geology, 190(1-2), 397-420. 
Gazioğlu, C., Yucel, Z.Y.,Dogan, E., 2005. Morphological features of major submarine landslides of Marmara Sea using multibeam data. Journal of Coastal Research, 21(4), 664-673, doi: 10.2112/03-0060.1.

Géli, L., Henry, P., Zitter, T., Dupre, S., Tryon, M., Çağatay, M.N., de Lépinay, B.M., Le Pichon, X., Şengör, A.M.C., Görür, N., Natalin, B., Uçarkuş, G., Oezeren, S., Volker, D., Gasperini, L., Burnard, P., Bourlange, S.,Party, M.S., 2008. Gas emissions and active tectonics within the submerged section of the North Anatolian Fault zone in the Sea of Marmara. Earth and Planetary Science Letters, 274(1-2), 34-39, doi: 10.1016/j.epsl.2008.06.047.

Gökçeoğlu, C., Tunusluoglu, M.C., Gorum, T., Tur, H., Gokasan, E., Tekkeli, A.B., Batuk, F.,Alp, H., 2009. Description of dynamics of the Tuzla Landslide and its implications for further landslides in the northern slope and shelf of the Cinarcik Basin (Marmara Sea, Turkey). Engineering Geology, 106(3-4), 133-153, doi:10.1016/j.enggeo.2009.02.007.

Görür, N.,Çağatay, M.N., 2010. Geohazards rooted from the northern margin of the Sea of Marmara since the late Pleistocene: a review of recent results. Natural Hazards, 54(2), 583-603, doi: 10.1007/s11069-009-9469-x.

Guglielmi, Y.,Cappa, F., 2010. Regional-scale relief evolution and large landslides: Insights from geomechanical analyses in the Tinee Valley (southern French Alps). Geomorphology, 117(12), 121-129, doi:10.1016/j.geomorph.2009.11.016.

Grall, C., Henry, P., Tezcan, D., Lépinay, B.M.d., Bécel, A., Géli, L., Rudkiewicz, J.-L., Zitter, T.,harmégnies, F., 2012. Heat flow in the sea of Marmara Central Basin, possible implications for the tectonic evolution of the North Anatolian fault. Geology (in press), doi:10.1130/G32192.1

Gürbüz, C., Aktar, M., Eyidogan, H., Cisternas, A., Haessler, H., Barka, A., Ergin, M., Turkelli, N., Polat, O., Ucer, S.B., Kuleli, S., Baris, S., Kaypak, B., Bekler, T., Zor, E., Bicmen, F.,Yoruk, A., 2000. The seismotectonics of the Marmara region (Turkey): results from a microseismic experiment. Tectonophysics, 316(1-2), 1-17. 
Halbach, P., Kuş̧̧u, I., Kuhn, T., Pekdeger, A.,Seifert, R., 2000. Methane in sediments of the deep Marmara Sea and its relation to local tectonic structures (abstract). In: N. Görür (Editor), NATO advanced Research Seminar: integration of earth sciences research on the 1999 Turkish and Greek earthquakes and needs for future cooperative research. Tubitak, Istanbul, pp. 74.

Hébert, H., Schindele, F., Altinok, Y., Alpar, B.,Gazioğlu, C., 2005. Tsunami hazard in the Marmara Sea (Turkey): a numerical approach to discuss active faulting and impact on the Istanbul coastal areas. Marine Geology, 215(1-2), 23-43, doi: 10.1016/j.margeo.2004.11.006.

Hovland, M., Orange, D., Bjorkum, P.A.,Gudmestad, O.T., 2001. Gas hydrate and seeps - Effects on slope stability: The "hydraulic model". Proceedings of the Eleventh (2001) International Offshore and Polar Engineering Conference, Vol I, 471-476.

Imren, C., Le Pichon, X., Rangin, C., Demirbag, E., Ecevitoglu, B.,Görür, N., 2001. The North Anatolian Fault within the Sea of Marmara : a new interpretation based on multi-channel seismic and multi-beam bathymetry data. Earth Planet. Sci. Lett., 186, 143-158.

Karabulut, H., Bouin, M.P., Bouchon, M., Dietrich, M., Cornou, C.,Aktar, M., 2002. The seismicity in the eastern Marmara Sea after the 17 August 1999 Izmit earthquake. Bulletin of the Seismological Society of America, 92(1), 387-393.

Karabulut, H., osalabey, S., Taymaz, T., Aktar, M., Selvi, O.,Kocaoglu, A., 2003. A tomographic image of the shallow crustal structure in the Eastern Marmara. Geophys. Res. Lett., 30, 2277.

Karabulut, H., Schmittbuhl, J., Ozalaybey, S., Lengline, O., Komec-Mutlu, A., Durand, V., Bouchon, M., Daniel, G.,Bouin, M.P., 2011. Evolution of the seismicity in the eastern Marmara Sea a decade before and after the 17 August 1999 Izmit earthquake. Tectonophysics, 510(1-2), 1727, doi:10.1016/j.tecto.2011.07.009.

Kastens, K.A., Cita, M.B., 1981. Tsunami-induced transport in the abyssal Mediterranean Sea. Geological Society of America Bulletin, 92, 845-857. 
Kenyon, N.H., Klaucke, I., Millington, J.,Ivanov, M.K., 2002. Sandy submarine canyon-mouth lobes on the western margin of Corsica and Sardinia, Mediterranean Sea. Marine Geology, 184(1-2), 69-84.

Kuş̧u, I., Okamura, M., Matsuoka, H., Gokasan, E., Awata, Y., Tur, H.,Simsek, M., 2005. Seafloor gas seeps and sediment failures triggered by the August 17, 1999 earthquake in the Eastern part of the Gulf of Izmit, Sea of Marmara, NW Turkey. Marine Geology, 215, 193-214.

Lamarche, G., Lurton, X., Verdier, A.L.,Augustin, J.M., 2011. Quantitative characterisation of seafloor substrate and bedforms using advanced processing of multibeam backscatter-Application to Cook Strait, New Zealand. Continental Shelf Research, 31(2), S93-S109, doi:10.1016/j.csr.2010.06.001.

Lee, H.J., Syvitski, J.P.M., Parker, G., Orange, D., Locat, J., Hutton, E.W.H.,Imran, J., 2002. Distinguishing sediment waves from slope failure deposits: field examples, including the 'Humboldt slide' and modelling results. Marine Geology, 192(1-3), 79-104, doi:Pii S00253227(02)00550-9.

Lee, S.H., Chough, S.K., 2001. High-resolution (2-7 kHz) acoustic and geometric characters of submarine creep deposits in the South Korea Plateau, East Sea. Sedimentology, 48(3), 629644, doi:10.1046/j.1365-3091.2001.00383.x.

Le Pichon, X., Chamot-Rooke, N., Rangin, C., Şengör, A.M.C., 2003. The North Anatolian Fault in the Sea of Marmara. Journal of Geophysical Research, 108, 2179, doi:101029/2002JB001862.

Le Pichon, X., Şengör, A.M.C., Demirbag, E., Rangin, C., Imren, C., Armijo, R., Görür, N., Çağatay, N., Mercier de Lépinay, B., Meyer, B., Saatcilar, R.,Tok, B., 2001. The active main Marmara fault. Earth Planet. Sci. Lett., 192, 595-616.

Leynaud, D., Mienert, J.,Nadim, F., 2004. Slope stability assessment of the Helland Hansen area offshore the mid-Norwegian margin. Marine Geology, 213(1-4), 457-480, doi:DOI 10.1016/j.margeo.2004.10.019. 
Loncke, L., Droz, L., Gaullier, V., Basile, C., Patriat, M.,Roest, W., 2009a. Slope instabilities from echocharacter mapping along the French Guiana transform margin and Demerara abyssal plain. Marine and Petroleum Geology, 26(5), 711-723, doi: 10.1016/j.marpetgeo.2008.02.010.

Loncke, L., Gaullier, V., Droz, L., Ducassou, E., Migeon, S.,Mascle, J., 2009b. Multi-scale slope instabilities along the Nile deep-sea fan, Egyptian margin: A general overview. Marine and Petroleum Geology, 26(5), 633-646, doi: 10.1016/j.marpetgeo.2008.03.010.

Loncke, L., Gaullier, V., Mascle, J., Vendeville, B.,Camera, L., 2006. The Nile deep-sea fan: An example of interacting sedimentation, salt tectonics, and inherited subsalt paleotopographic features. Marine and Petroleum Geology, 23(3), 297-315, doi:DOI 10.1016/j.marpetgeo.2006.01.001.

Major, C., Ryan, W., Lericolais, G.,Hajdas, I., 2002. Constraints on Black Sea outflow to the Sea of Marmara during the last glacial-interglacial transition. Marine Geology, 190(1-2), 19-34.

McAdoo, B.G., Pratson, L.F.,Orange, D.L., 2000. Submarine landslide geomorphology, US continental slope. Marine Geology, 169(1-2), 103-136.

McHugh, C.M.G., Gurung, D., Giosan, L., Ryan, W.B.F., Mart, Y., Sancar, U., Burckle, L.,Çağatay, M.N., 2008. The last reconnection of the Marmara Sea (Turkey) to the World Ocean: A paleoceanographic and paleoclimatic perspective. Marine Geology, 255(1-2), 64-82, doi: 10.1016/j.margeo.2008.07.005.

McHugh, C.M.G., Seeber, L., Cormier, M.H., Dutton, J., Çağatay, N., Polonia, A., Ryan, W.B.F.,Görür, N., 2006. Submarine earthquake geology along the North Anatolia Fault in the Marmara Sea, Turkey: A model for transform basin sedimentation. Earth and Planetary Science Letters, 248(3-4), 661-684, doi: 10.1016/j.epsl.2006.05.038.

Menot, G.,Bard, E., 2010. Geochemical evidence for a large methane release during the last deglaciation from Marmara Sea sediments. Geochimica Et Cosmochimica Acta, 74(5), 15371550, doi: 10.1016/j.gca.2009.11.022. 
Mienert, J., Vanneste, M., Bunz, S., Andreassen, K., Haflidason, H.,Sejrup, H.P., 2005. Ocean warming and gas hydrate stability on the mid-Norwegian margin at the Storegga Slide. Marine and Petroleum Geology, 22(1-2), 233-244, doi: 10.1016/j.marpetgeo.2004.10.018.

Mulder, T.,Cochonat, P., 1996. Classification of offshore mass movements. Journal of Sedimentary Research, 66(1), 43-57.

Mulder, T., Gonthier, E., Lecroart, P., Hanquiez, V., Marches, E.,Voisset, M., 2009. Sediment failures and flows in the Gulf of Cadiz (eastern Atlantic). Marine and Petroleum Geology, 26(5), 660672.

Okay, A.I., Demirbag, E., Kurt, H., Okay, N., Kuşçu, I., 1999. An active, deep marine strike-slip basin along the North Anatolian fault in Turkey. Tectonics, 18, 129-147.

Okay, A., I., Tüysüz, O.,S., K., 2004. From transpression to transtension: changes in morphology and structure around a bend on the North Anatolian Fault in the Marmara region. Tectonophysics, 391(1-4), 259-282, doi:10.1016/j.tecto.2004.07.016.

Orange, D.L., Greene, H.G., Reed, D., Martin, J.B., McHugh, C.M., Ryan, W.B.F., Maher, N., Stakes, D.,Barry, J., 1999. Widespread fluid expulsion on a translational continental margin: Mud volcanoes, fault zones, headless canyons, and organic-rich substrate in Monterey Bay, California. Geological Society of America Bulletin, 111(7), 992-1009.

Örgülü, G., 2011. Seismicity and source parameters for small-scale earthquakes along the splays of the North Anatolian Fault (NAF) in the Marmara Sea. Geophysical Journal International, 184(1), 385-404, doi:10.1111/j.1365-246X.2010.04844.x.

Özeren, M.S., Çağatay, M.N., Postacioglu, N., Şengör, A.M.C., Görür, N.,Eris, K., 2010. Mathematical modelling of a potential tsunami associated with a late glacial submarine landslide in the Sea of Marmara. Geo-Marine Letters, 30(5), 523-539, doi:DOI 10.1007/s00367-010-0191-1.

Parke, J.R., Minshull, T.A., Anderson, G., White, R.S., McKenzie, D., Kuşçu, I., Bull, J.M., Görür, N., Şengör, C., 1999. Active faults in the Sea of Marmara, western Turkey, imaged by seismic reflection profiles. Terra Nova, 11, 223-227. 
Parke, J.R., White, R.S., McKenzie, D., Minshull, T.A., Bull, J., Kuşçu, I., Görür, N., Şengör, C., 2002. Interaction between faulting and sedimentation in the sea of Marmara, western Turkey. J; Geophys. Res., 107(B11), doi:10.1029/2001JB000450

Parsons, T., 2004. Recalculated probability of $M>=7$ earthquakes beneath the Sea of Marmara, Turkey. Journal of Geophysical Research-Solid Earth, 109(B5), B05304, doi: 10.1029/2003jb002667.

Piper, D.J.W., Pirmez, C., Manley, P.L., Long, D., Flood, R.D., Normark, W.R.,Showers, W., 1997. Masstransport deposits of the Amazon fan. In: R.D. Flood, D.J.W. Piper, A. Klaus,L.C. Peterson (Editors), Proceedings of the Ocean Drilling Program, Scientific Results 155. College Station, TX.

Polonia A., Cormier, M.H., Çagatay, M.N., Bortoluzzi, G., Bonatti, E., Gasperini, L., Seeber,L., Görür, N., Capotondi, L., McHugh, C.M.G., Ryan, W.B.F., Emre, Ö., Okay, N., Ligi, M., Tok, B., Blasi, A., Busetti, M., Eris, K., Fabretti,P., Fielding, E.J., Imren, C., Kurt, H., Magagnoli, A., Marozzi, G., Ozer, N., Penitenti, D., Serpi, G., Sarikavak, K., 2002. Exploring submarine earthquake geology in the Marmara Sea, EOS Transactions AGU, 83, 229 and 235-236.

Rangin, C., Le Pichon, X., Demirbag, E.,Imren, C., 2004. Strain localization in the Sea of Marmara: Propagation of the North Anatolian Fault in a now inactive pull-apart. Tectonics, 23, TC2014, doi:10.1029/2002TC001437.

Reichel, T.,Halbach, P., 2007. An authigenic calcite layer in the sediments of the Sea of Marmara--A geochemical marker horizon with paleoceanographic significance. Deep Sea Research Part II: Topical Studies in Oceanography, 54(11-13), 1201-1215.

Ryan, W.B.F., Major, C.O., Lericolais, G.,Goldstein, S.L., 2003. Catastrophic Flooding of the Black Sea. Annu. Rev. Earth Planet. Sci., 31, 525-554.

Ryan, W.B.F., Pitman, W.C., Major, C.O., Shimkus, K., Moskalenko, V., Jones, G.A., Dimitrov, P., Görür, N., Sakinc, M.,Yuce, H., 1997. An abrupt drowning of the Black Sea shelf. Marine Geology, $138(1-2), 119-126$ 
Sato, T., Kasahara, J., Taymaz, T., Ito, M., Kamimura, A., Hayakawa, T.,Tan, O., 2004. A study of microearthquake seismicity and focal mechanisms within the Sea of Marmara (NW Turkey) using ocean bottom seismometers (OBSs). Tectonophysics, 391(1-4), 303-314, doi:10.1016/j.tecto.2004.07.018.

Sanchez, G., Rolland, Y., Corsini, M., Braucher, R., Bourles, D., Arnold, M.,Aumaitre, G., 2010. Relationships between tectonics, slope instability and climate change: Cosmic ray exposure dating of active faults, landslides and glacial surfaces in the SW Alps. Geomorphology, 117(12), 1-13, doi:10.1016/j.geomorph.2009.10.019.

Seeber, L., Cormier, M.H., McHugh, C., Emre, O., Polonia, A.,Sorlien, C., 2006. Rapid subsidence and sedimentation from oblique slip near a bend on the North Anatolian transform fault in the Marmara Sea, Turkey. Geology, 34(11), 933-936, doi: 10.1130/G22520a.1.

Seeber, L., Emre, O., Cormier, M.H., Sorlien, C.C., McHugh, C.M.G., Polonia, A., Ozer, N.,Çağatay, N., 2004. Uplift and subsidence from oblique slip: the Ganosâ€"Marmara bend of the North Anatolian Transform, western Turkey. Tectonophysics, 391(1-4), 239-258.

Şengör, A.M.C., 2011. Istanbul Bođazi niçin Bođaziçi'nde açilmiptir? In: D. Ekinci (Editor), Fiziki Cografya Araptirmalari Sistematik ve Bolgesel- Profesör Doktor Mehmet Yildiz Hosgoren'e Armagan, Türk, Cografya Kurumu Yayinlari, sayý 6, Istanbul, pp. 55-102.

Şengör, A.M.C., Görür, N.,Saroglu, F., 1985. Strike-slip faulting and related basin formation in zones of tectonic escape : Turkey as a case study. In: K.T. Biddle,N.C. Blick (Editors), Strike-slip deformation, basin formation and sedimentation. Soc. Econ. Paleon. Mine. Spec. Publication, pp. 227-264.

Şengör, A.M.C., Tuysuz, O., Imren, C., Sakinc, M., Eyidogan, H., Görür, G., Le Pichon, X.,Rangin, C., 2005. The North Anatolian Fault: A new look. Annual Review of Earth and Planetary Sciences, $33,37-112$.

Shillington, D.J., Seeber, L., Sorlien, C.C., Steckler, M.S., Kurt, H., Dondurur, D., Cifci, G., Imren, C., Cormier, M.H., McHugh, C.M.G., Gurcay, S., Poyraz, D., Okay, S., Atgin, O.,Diebold, J.B., 2012. 
Evidence for widespread creep on the flanks of the Sea of Marmara transform basin from marine geophysical data. Geology, 40(5), 439-442, doi:10.1130/g32652.1.

Stanley, D.J.,Blanpied, C., 1980. Late Quaternary Water Exchange between the Eastern Mediterranean and the Black-Sea. Nature, 285(5766), 537-541.

Tary, J.B., Géli, L., Henry, P., Natalin, B., Gasperini, L., Comoglu, M., Çağatay, N.,Bardainne, T., 2011. Sea-Bottom Observations from the Western Escarpment of the Sea of Marmara. Bulletin of the Seismological Society of America, 101(2), 775-791, doi:10.1785/0120100014.

Tryon, M.D., Henry, P., Çağatay, M.N., Zitter, T.A.C., Géli, L., Gasperini, L., Burnard, P., Bourlange, S.,Grall, C., 2010. Pore fluid chemistry of the North Anatolian Fault Zone in the Sea of Marmara: A diversity of sources and processes. Geochemistry Geophysics Geosystems, 11, Q0ad03 , doi: 10.1029/2010gc003177.

Tripsanas, E.K., Piper, D.J.W.,Campbell, D.C., 2008. Evolution and depositional structure of earthquake-induced mass movements and gravity flows: Southwest Orphan Basin, Labrador Sea. Marine and Petroleum Geology, 25(7), 645-662, doi: 10.1016/j.marpetgeo.2007.08.002.

Tur, H., 2007. An example of secondary fault activity along the north Anatolian Fault on the NE Marmara Sea Shelf, NW Turkey. Earth Planets and Space, 59(6), 541-552.

Vidal, L., Menot, G., Joly, C., Bruneton, H., Rostek, F., Çağatay, M.N., Major, C.,Bard, E., 2010. Hydrology in the Sea of Marmara during the last 23 ka: Implications for timing of Black Sea connections and sapropel deposition. Paleoceanography, 25, Pa1205, doi: 10.1029/2009pa001735.

Yalciner, A.C., Alpar, B., Altinok, Y., Ozbay, I.,Imamura, F., 2002. Tsunamis in the Sea of Marmara Historical documents for the past, models for the future. Marine Geology, 190(1-2), 445-463.

Yaltirak, C., 2002. Tectonic evolution of the Marmara Sea and its surroundings. Marine Geology, 190(1-2), 493-529.

Zitter, T.A.C., Henry, P., Aloisi, G., Delaygue, G., Çağatay, M.N., de Lépinay, B.M., Al-Samir, M., Fornacciari, F., Tesmer, M., Pekdeger, A., Wallmann, K.,Lericolais, G., 2008. Cold seeps along 

Oceanographic Research Papers, 55(4), 552-570, doi: 10.1016/j.dsr.2008.01.002.

Figure legends

801

802

803

804

805

Figure 1: (a) Active tectonics of the eastern Mediterranean Sea showing the study area (SOM: Sea of Marmara) along the North Anatolian Fault. NAFZ: North Anatolian Fault Zone - EAFZ: East Anatolian Fault Zone - DSTFZ: Dead Sea Transform Fault Zone. (b) Multibeam backscatter image of the Sea of Marmara with simplified sketch of the North Anatolian fault system (modified after Le Pichon et al., 2001, Grall et al., 2012; see Fig. 3 for a detailed structural map). Insets indicate the location of Fig. 2, Fig. 4, Fig. 5, Fig. 6, Fig. 7, Fig. 8, and Fig. 9. Abbreviations are as follow: TB: Tekirdağ Basin; CB: Central Basin; KB: Kumburgaz Bain; CnB: Çınarcık Basin; WH: Western High; CH: Central High; GoG: Gulf of Gemlik; Gol: Gulf of Izmit; Iml: Imralı Island; AP: Armutlu Peninsula.

Figure 2: Characteristics of the mass wasting features within the different datasets: (a) slope gradient map showing curved slope failure scars, canyons, erosional gullies and slide toes; (b1) transparent, (b2) hummocky and (b3) hyperbolic chirp echo-characteristics corresponding to the mass wasting deposits; (c) sedimentary sequence within cores; (d) visual observation of avalanche debris deposits from Nautile dive.

Figure 3: Map of the mass wasting features, active faults, canyons and fluid seepage areas in the Sea of Marmara. Multibeam bathymetric data from Rangin et al. (2001), active faults modified after Le Pichon et al. (2003) and seepage sites modified after Zitter et al. (2008) and Géli et al. (2008).

Figure 4: (a) Shaded bathymetric and (b) slope gradient map of Çınarcık Basin, derived from EM300 multibeam data (38 $\mathrm{m}$ grid cell).

Figure 5: (a) Slope gradient map, derived from EM300 multibeam data (38 m grid cell), of the Tuzla Complex with the dive track and MTA seismic line location; in bold the section shown in (c). Slope gradient colour scale is the same as on Fig. 4. (b) Dive 1652 pictures of the Tuzla Complex headscarp showing outcrop of palaeozoic black shales with corals. (c) MTA multichannel seismic section 
obtained on board the R/V Sismik1 (and processed by Caner Imren) across the Tuzla Landslide

824 Complex, showing the rotational blocks and the headscarp. Modified after Özeren et al. (2010).

825

Figure 6: Shaded bathymetric map derived from multibeam EM300 data (38 m grid cell), dive track and dive pictures of Marnaut dive 1653 on the Yalova Complex, south of the Çınarcık Basin (location on Fig. 1) showing undraped chaotic blocks of authigenic carbonate crusts and evidence of fluid seepage (black patches and white bacterial mats). Bathymetric colour range is same as on Fig. 4.

Figure 7: Marmarascarps profile (3.5kHz frequency) across the base of the northern Çınarcık slope where scree is observed on seafloor pictures (chaotic blocks and fallen boulders). The scree at the base of the cliff is also observed on the bathymetric data (orange area). Red stars indicate the location of recognised fluid seepages from Nautile and ROV observations (black reduced sediments patches with white bacterial mats).

Figure 8: (a) Shaded bathymetric map (colour range is same as on Fig. 4), (b) slope gradient map and (c) slope-facing map (aspect map) of the Ganos Landslide Complex in the Tekirdağ Basin, derived from multibeam EM300 data with a grid cell resolution of $38 \mathrm{~m}$. Aspect is the direction of maximum slope gradient, and slope gradient is the dip for each grid cell based on the elevation of its nearest neighbors. (d) The morpho-structural sketch (canyons in purple, landslides and slope failures in grey and faults in red) is interpreted from multibeam and backscatter data, and the active structures are modified after Le Pichon et al. (2003). (e) Topographic profile along the major slope. Note the small staircase-like scarps perpendicular to the slope, interpreted as creep (see Shillington et al., 2012), and the multiple slope failures in the upper part of the slide, on the extremity of Ganos fault segment.

Figure 9: (a) Shaded relief map of Tekirdağ Basin with location of chirp lines and cores. Inset indicates the location of (b): Slope gradient map zoomed on the canyons showing scars on the flanks and within the thalweg. Slope gradient colour scale is the same as on Fig. 4 . White coloured lines are $5 \mathrm{~m}$ isobaths. (c) Marnaut 16 chirp profile (3.5 kHz frequency) across a canyon showing the infill of the canyon. 
Figure 10: Lithology and sedimentary sequence interpretation for cores MD042737 and MD042740

850 (Marion Dufresne calypso cores) and MNTKS30 (Marnaut kullenberg core) in the Tekirdağ Basin, at

851

852

853

854

855

856

857

858

859

860

861

862

863

864

865

866

867

868

869

870

871

872

873

the mouth of the canyon (see Fig. 9 for location). Detailed sections of the cores are illustrated with photographs and Scopix XRay images.

Figure 11: Marnaut 95 chirp profile (frequency of $3.5 \mathrm{kHz}$ ) in the Tekirdağ Basin showing a buried submarine landslide (transparent lens) intercalated within sediments. For location, see Fig. 9. The correlation of the strong reflective horizons (also noted a,b,c and d in Fig. 11 in Zitter el al. 2008) with the core MD042737 indicates that this submarine landslide must have occurred at the beginning of marine stage in the Sea of Marmara.

Figure 12: (a) Micro-seismicity records from Sato et al. (2004), Karabulut et al. (2002) and Örgülü et al. (2011) projected on multibeam shaded relief map of Çınarcık Basin, including the Tuzla and Yalova complexes with focal mechanisms modified after Karabulut et al. (2002), (compressional quadrants in red). (b) Micro-seismicity records from Sato et al. (2004) and Örgülü et al. (2011) projected on multibeam shaded relief map of Tekirdağ Basin, including the Ganos Complex.

Table 1: Table presenting the mean slope gradient of the main margins and major submarine landslides determined within polygons defined in areas of similar steepness and centered at the indicated longitude and latitude.

Table 2: Table summarizing the mass wasting features presented within this study and mapped in Fig. 3, with their location, their name or context, their surface, length and width, their age known from this study or from the literature and the inferred processes that generate them. References to studies dealing with some of these mass wasting features are indicated within this table with numbers as follows: 1: Gazioğlu et al., 2002; 2: Gazioğlu et al., 2005; 3: Tur, 2007; 4: Gökçeoğlu et al., 2009; 5: Görür and Çağatay, 2010; 6: Özeren et al., 2010; 7: Shillington et al., 2012. 
Location Slope average $\left({ }^{\circ}\right) \quad$ Number of cells

Slopes:

NE Tekirdag

N Tekirdag

S Tekirdag

W Western High

E Western High

N Central Basin

$S$ Central Basin

SE Central Basin

N Kumburgaz

S Kumburgaz

W Central High

E Central High

NW Cinarcik

N Cinarcik

S Cinarcik

SE Cinarcik

Mass wasting features:

S Ganos landslide

N Ganos landslide

Tuzla landslide headscarp

E Tuzla landslide

Mass feature 32
19.25

8.21

7.93

7.93

7.17

11.45

8.34

4.00

5.30

4.35

2.68

3.69

15.87

23.11

11.84

17.28

5.65

9.42

21.04

14.44

10.14

Area $(\mathrm{km} 2) \quad$ Center longitude Center latitude

$\begin{array}{rrrr}26622 & 38.81 & 27^{\circ} 28^{\prime} 49.45^{\prime \prime} \text { E } & 40^{\circ} 50^{\prime} 6.69^{\prime \prime} \mathrm{N} \\ 56081 & 83.10 & 27^{\circ} 40^{\prime} 59.25^{\prime \prime} \mathrm{E} & 40^{\circ} 53^{\prime} 52.88^{\prime \prime} \mathrm{N} \\ 146414 & 216.20 & 27^{\circ} 32^{\prime} 10.89^{\prime \prime} \mathrm{E} & 40^{\circ} 44^{\prime} 46.93^{\prime \prime} \mathrm{N} \\ 36635 & 53.93 & 27^{\circ} 42^{\prime} 8.26^{\prime \prime} \mathrm{E} & 40^{\circ} 49^{\prime} 16.79^{\prime \prime} \mathrm{N} \\ 12783 & 18.80 & 27^{\circ} 53^{\prime} 37.07^{\prime \prime} \mathrm{E} & 40^{\circ} 49^{\prime} 9.47^{\prime \prime} \mathrm{N} \\ 100173 & 147.60 & 28^{\circ} 3^{\prime} 44.35^{\prime \prime} \mathrm{E} & 40^{\circ} 54^{\prime} 50.78^{\prime \prime} \mathrm{N} \\ 126747 & 186.44 & 27^{\circ} 59^{\prime} 21.21^{\prime \prime} \mathrm{E} & 40^{\circ} 43^{\prime} 29.13^{\prime \prime} \mathrm{N} \\ 70431 & 103.61 & 28^{\circ} 9^{\prime} 19.65^{\prime \prime} \mathrm{E} & 40^{\circ} 47^{\prime} 58.86^{\prime \prime} \mathrm{N} \\ 186127 & 275.23 & 28^{\circ} 21^{\prime} 6.50^{\prime \prime} \mathrm{E} & 40^{\circ} 54^{\prime} 3.36^{\prime \prime} \mathrm{N} \\ 38823 & 57.08 & 28^{\circ} 22^{\prime} 13.24^{\prime \prime} \mathrm{E} & 40^{\circ} 47^{\prime} 48.42^{\prime \prime} \mathrm{N} \\ 21818 & 32.09 & 28^{\circ} 29^{\prime} 9.98^{\prime \prime} \mathrm{E} & 40^{\circ} 50^{\prime} 57.84^{\prime \prime} \mathrm{N} \\ 103781 & 155.48 & 28^{\circ} 40^{\prime} 30.36^{\prime \prime} \mathrm{E} & 40^{\circ} 49^{\prime} 20.07^{\prime \prime} \mathrm{N} \\ 45535 & 69.15 & 28^{\circ} 47^{\prime} 15.86^{\prime \prime} \mathrm{E} & 40^{\circ} 53^{\prime} 36.72^{\prime \prime} \mathrm{N} \\ 34257 & 50.42 & 29^{\circ} 1^{\prime} 54.38^{\prime \prime} \mathrm{E} & 40^{\circ} 49^{\prime} 21.56^{\prime \prime} \mathrm{N} \\ 111849 & 164.89 & 28^{\circ} 57^{\prime} 44.04^{\prime \prime} \mathrm{E} & 40^{\circ} 42^{\prime} 14.78^{\prime \prime} \mathrm{N} \\ 33830 & 49.75 & 29^{\circ} 6^{\prime} 34.60^{\prime \prime} \mathrm{E} & 40^{\circ} 41^{\prime} 2.90^{\prime \prime} \mathrm{N} \\ & & & \\ 40677 & 60.16 & 27^{\circ} 27^{\prime} 52.22^{\prime \prime} \mathrm{E} & 40^{\circ} 45^{\prime} 9.78^{\prime \prime} \mathrm{N} \\ 15912 & 23.40 & 27^{\circ} 26^{\prime} 57.03^{\prime \prime} \mathrm{E} & 40^{\circ} 46^{\prime} 48.37^{\prime \prime} \mathrm{N} \\ 4644 & 6.84 & 29^{\circ} 14^{\prime} 46.26^{\prime \prime} \mathrm{E} & 40^{\circ} 45^{\prime} 2.08^{\prime \prime} \mathrm{N} \\ 9130 & 13.39 & 27^{\circ} 28^{\prime} 2.65^{\prime \prime} \mathrm{E} & 40^{\circ} 45^{\prime} 30.56^{\prime \prime} \mathrm{N} \\ 16046 & 23.63 & 29^{\circ} 19^{\prime} 1.25^{\prime \prime} \mathrm{E} & 40^{\circ} 42^{\prime} 42.36^{\prime \prime} \mathrm{N}\end{array}$




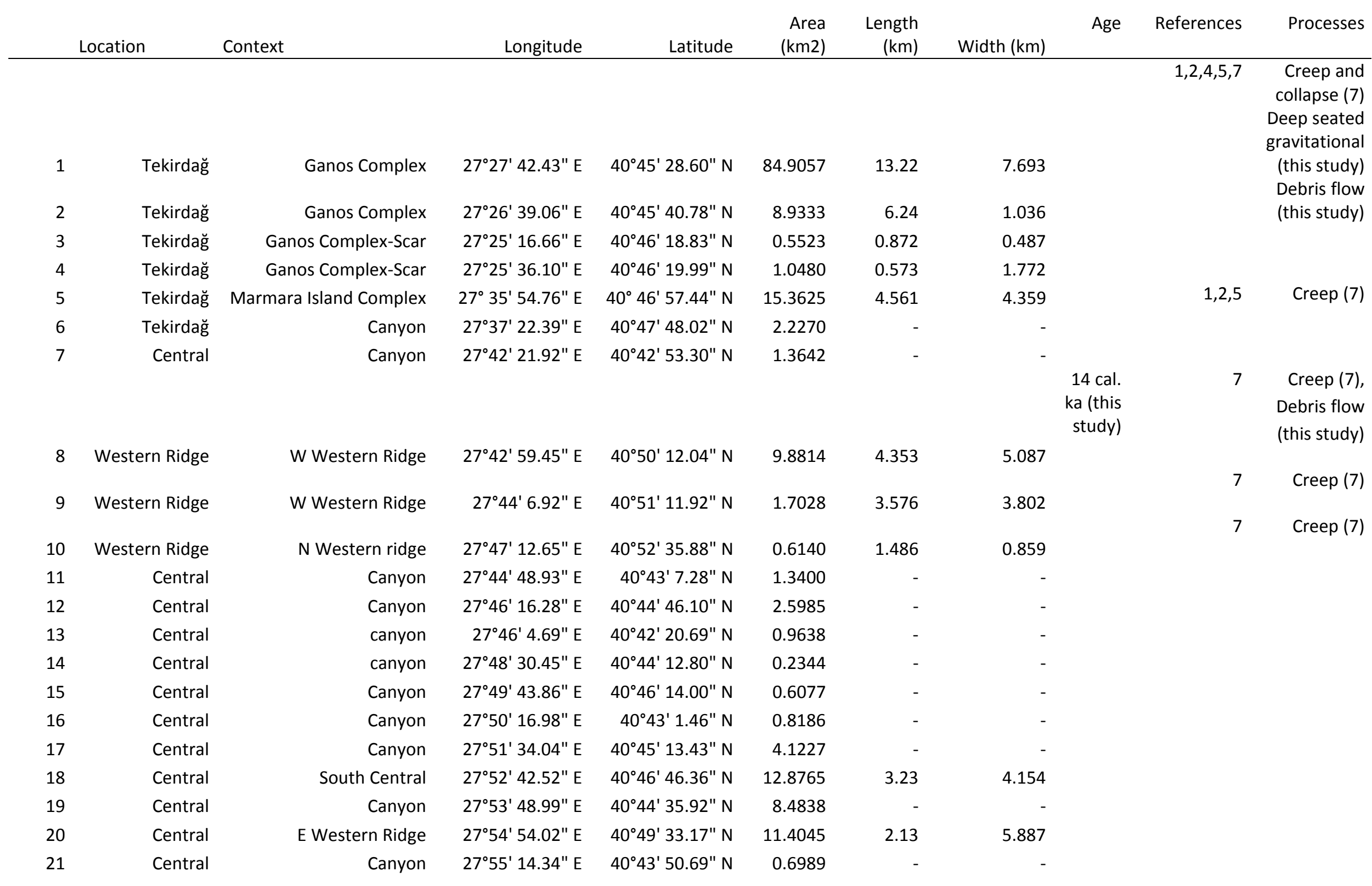




\begin{tabular}{|c|c|c|c|c|c|c|c|c|c|c|}
\hline 22 & Central & NE Central basin & $28^{\circ} 10^{\prime} 4.15^{\prime \prime} \mathrm{E}$ & $40^{\circ} 53^{\prime} 28.66^{\prime \prime} \mathrm{N}$ & 24.1570 & 7.644 & 3.308 & & 5 & \\
\hline \multirow[t]{2}{*}{23} & Central & flank NE Central & $28^{\circ} 8^{\prime} 8.51^{\prime \prime} \mathrm{E}$ & $40^{\circ} 50^{\prime} 1.98^{\prime \prime} \mathrm{N}$ & 2.7964 & 1.723 & 3.924 & & 7 & Creep (7) \\
\hline & & & & & & & & & 7 & Creep (7) \\
\hline \multirow[t]{2}{*}{24} & Central Ridge & S Kumburgaz & $28^{\circ} 23^{\prime} 53.46^{\prime \prime} \mathrm{E}$ & $40^{\circ} 47^{\prime} 51.77^{\prime \prime} \mathrm{N}$ & 29.6489 & 3.456 & 9.613 & & & \\
\hline & & & & & & & & & 2,7 & Creep (7) \\
\hline \multirow[t]{2}{*}{25} & Central Ridge & E Central Ridge & $28^{\circ} 38^{\prime} 45.58^{\prime \prime} \mathrm{E}$ & $40^{\circ} 48^{\prime} 22.04^{\prime \prime} \mathrm{N}$ & 58.0094 & 11.695 & 11.182 & & & \\
\hline & & & & & & & & & 7 & Creep (7) \\
\hline \multirow[t]{2}{*}{26} & Central Ridge & E Central Ridge & $28^{\circ} 41^{\prime} 52.62^{\prime \prime} \mathrm{E}$ & $40^{\circ} 51^{\prime} 41.97^{\prime \prime} \mathrm{N}$ & 8.4042 & 6.07 & 3.899 & & & \\
\hline & & & & & & & & & 7 & Creep (7) \\
\hline 27 & Çınarcık & South Çınarcık & $29^{\circ} 01^{\prime} 24.71^{\prime \prime} \mathrm{E}$ & $40^{\circ} 43^{\prime} 7.74^{\prime \prime} \mathrm{N}$ & 118.8027 & 5.67 & 26.75 & & & \\
\hline 28 & Çınarcık & N Çınarcık scree slope & $29^{\circ} 05^{\prime} 32.77^{\prime \prime} \mathrm{E}$ & $40^{\circ} 46^{\prime} 47.91^{\prime \prime} \mathrm{N}$ & 20.0913 & - & - & & & \\
\hline \multirow[t]{2}{*}{29} & Çınarcık & South East Çınarcık & $29^{\circ} 10^{\prime} 46.37^{\prime \prime} \mathrm{E}$ & $40^{\circ} 41^{\prime} 48.88^{\prime \prime} \mathrm{N}$ & 21.0210 & 3.52 & 5.85 & & 5 & \\
\hline & & & & & & & & $\begin{array}{r}17 \text { ka } \\
(6)\end{array}$ & $1,2,3,4,5,6,7$ & $\begin{array}{r}\text { Deep-seated } \\
\text { rotational } \\
(4,5, \text { this }\end{array}$ \\
\hline 30 & Çınarcık & Tuzla Complex & $29^{\circ} 13^{\prime} 27.30^{\prime \prime} \mathrm{E}$ & $40^{\circ} 45^{\prime} 2.48^{\prime \prime} \mathrm{N}$ & 39.3684 & 5.681 & 6.44 & & & study) \\
\hline 31 & Çınarcık & South East Çınarcık & $29^{\circ} 14^{\prime} 11.81^{\prime \prime} \mathrm{E}$ & $40^{\circ} 41^{\prime} 39.76^{\prime \prime} \mathrm{N}$ & 11.4806 & 5.287 & 2.193 & & & \\
\hline 32 & Çınarcık & Izmit Gulf & $29^{\circ} 19^{\prime} 22.42^{\prime \prime} \mathrm{E}$ & $40^{\circ} 42^{\prime} 29.12^{\prime \prime} \mathrm{N}$ & 33.5267 & 8.468 & 4.753 & & & \\
\hline
\end{tabular}









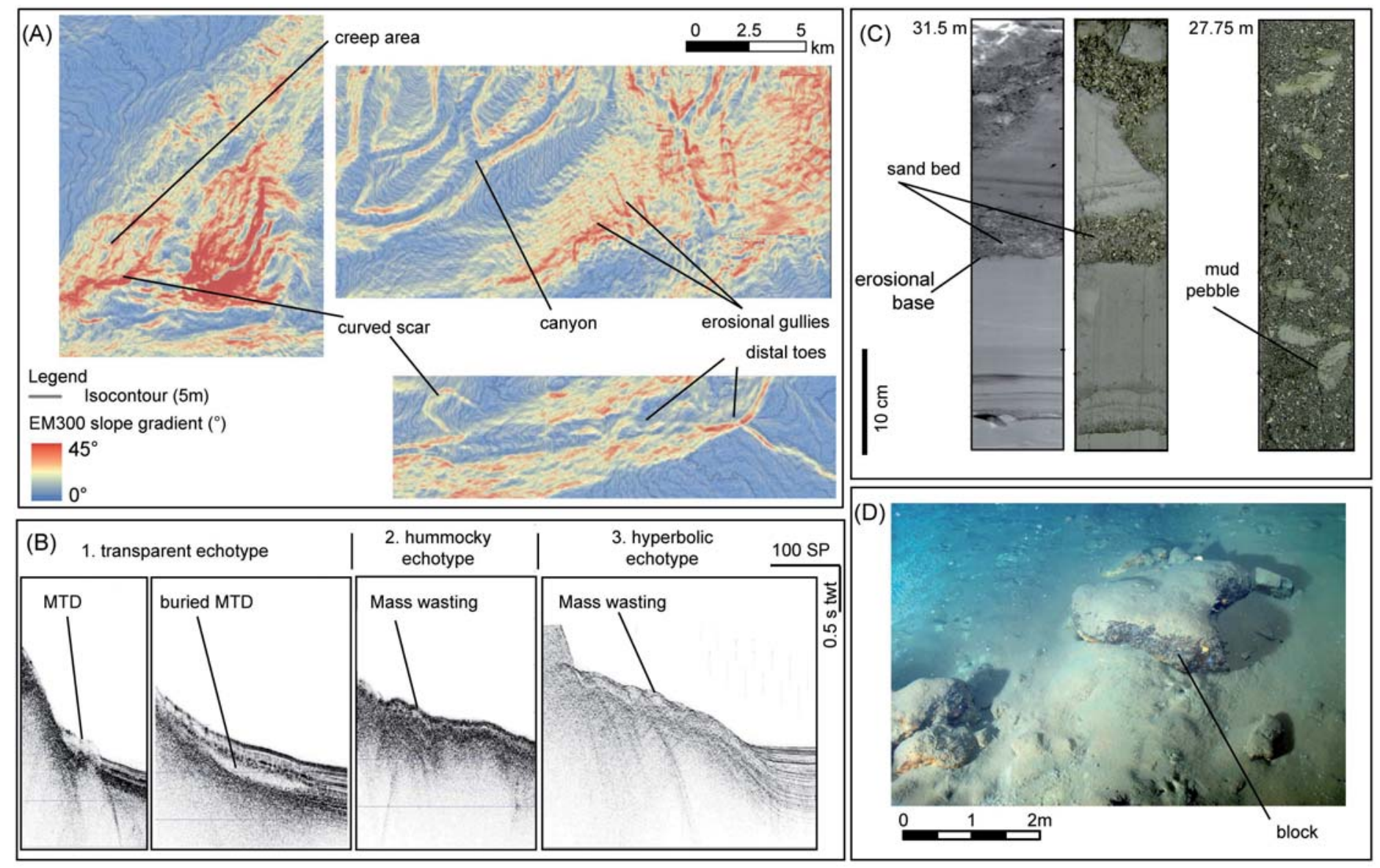




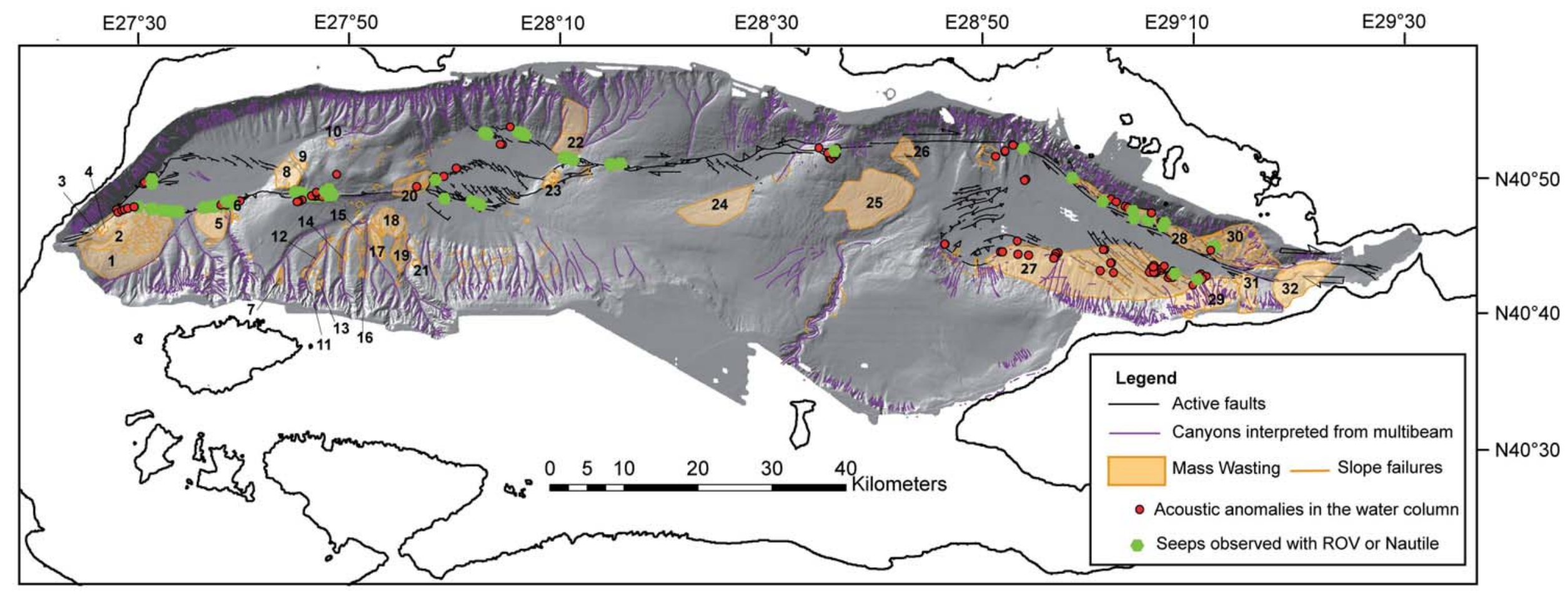




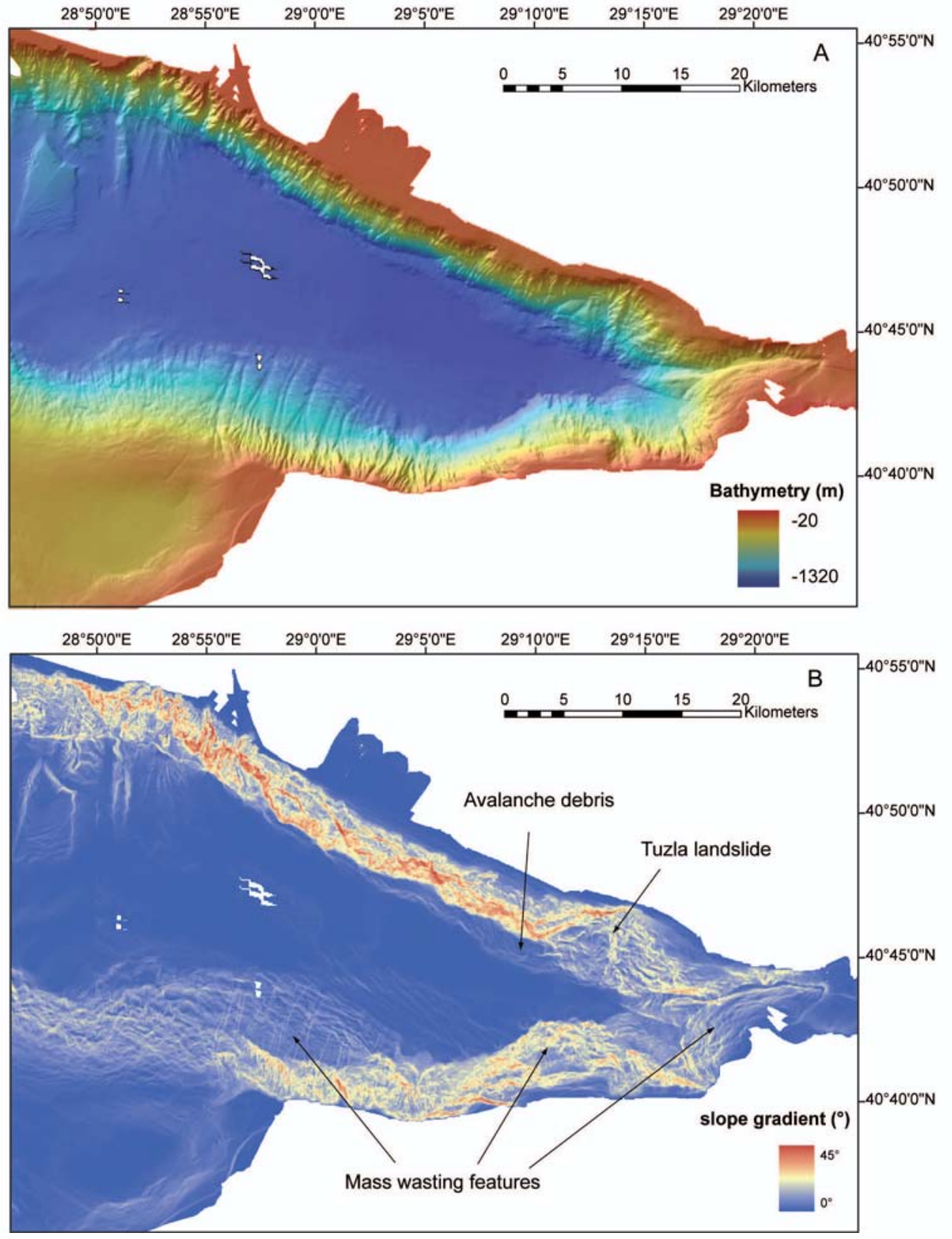




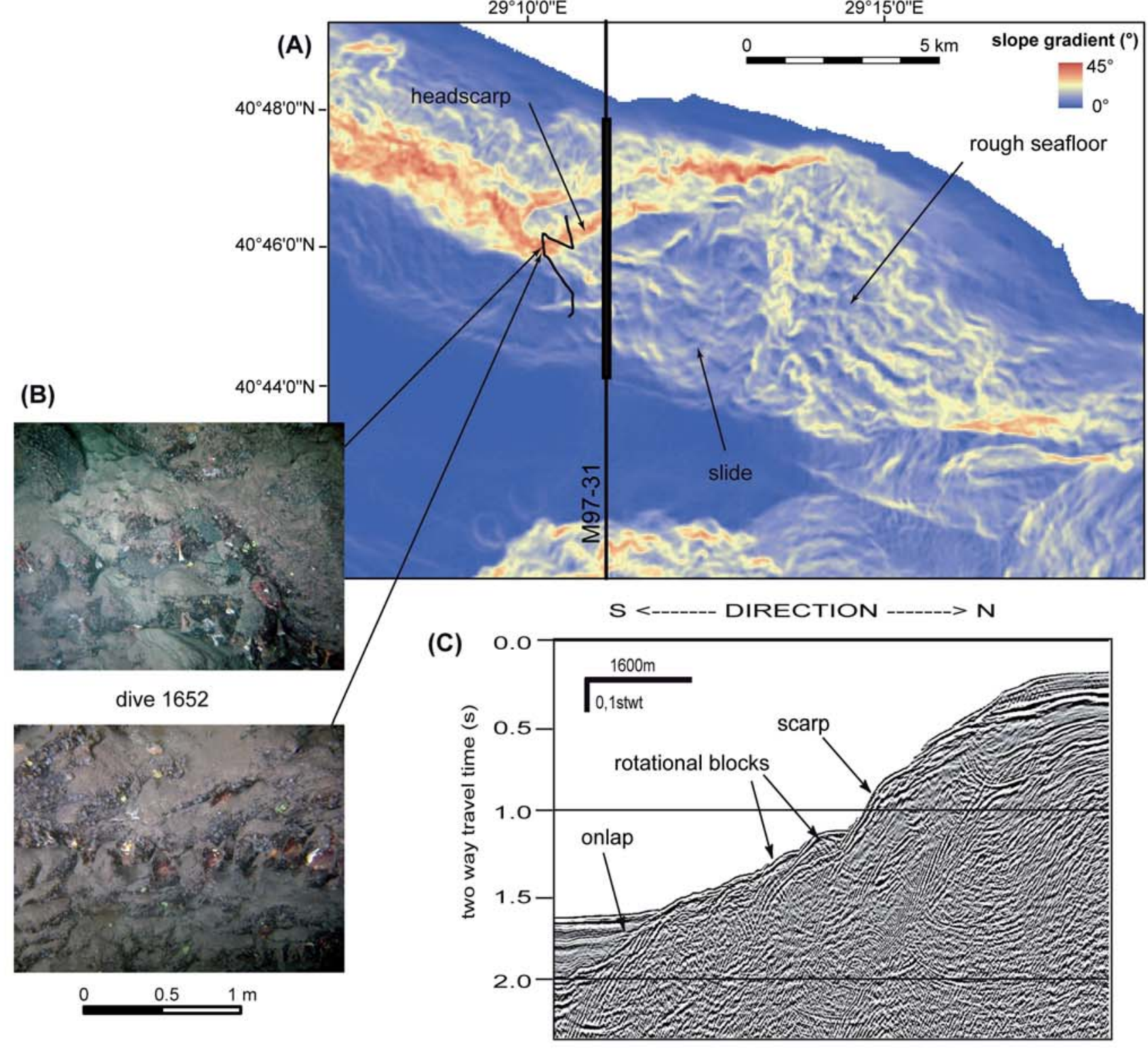




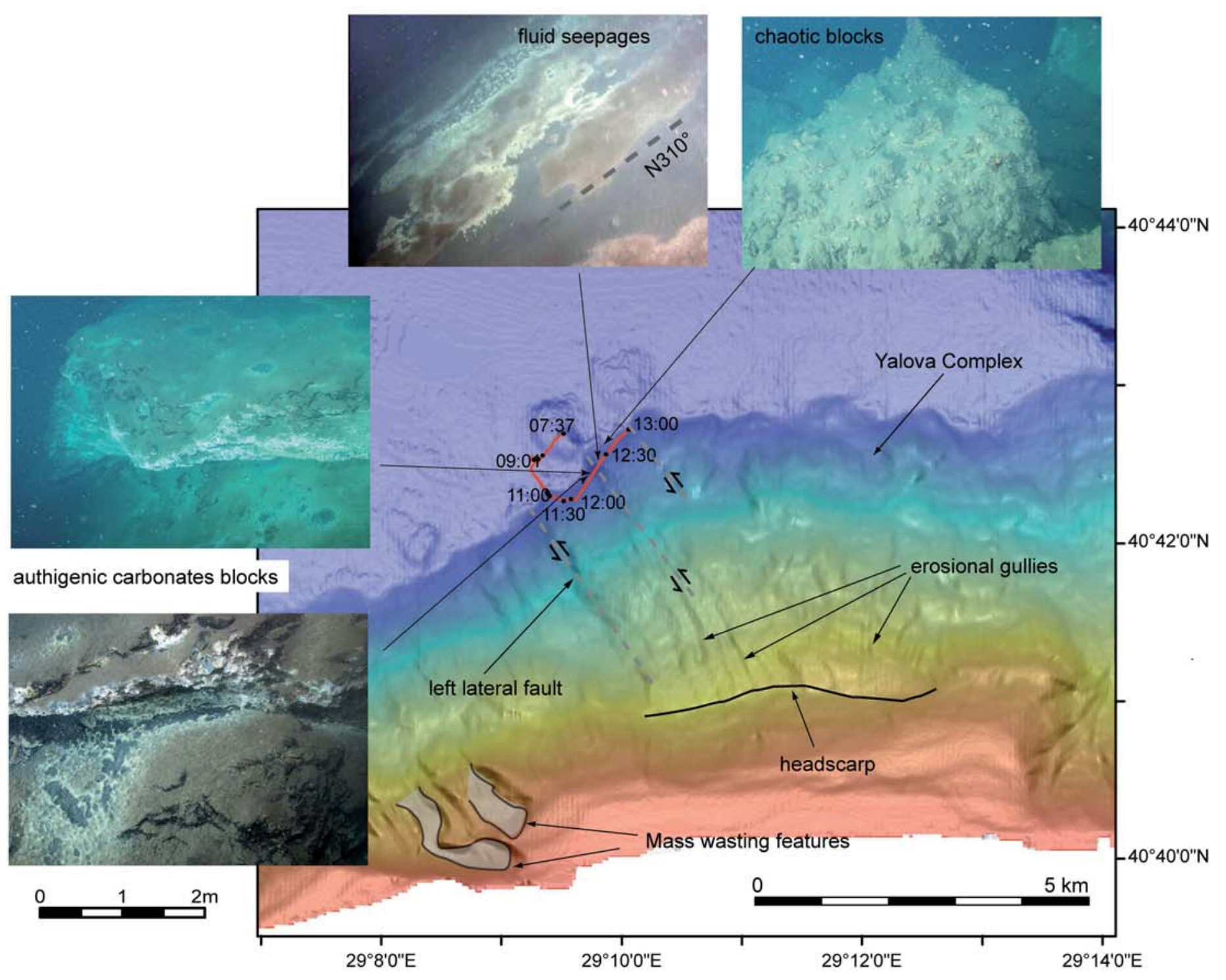




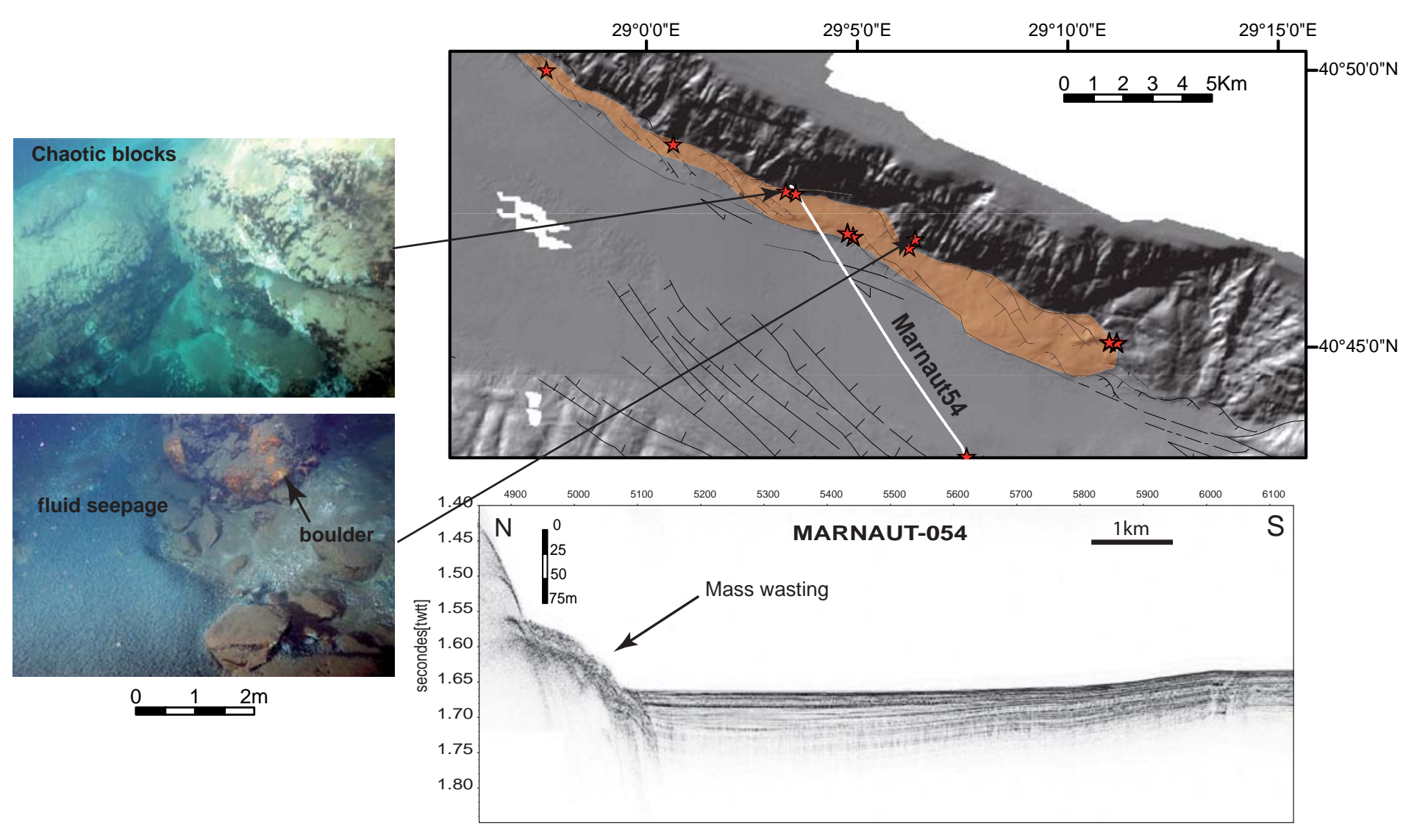



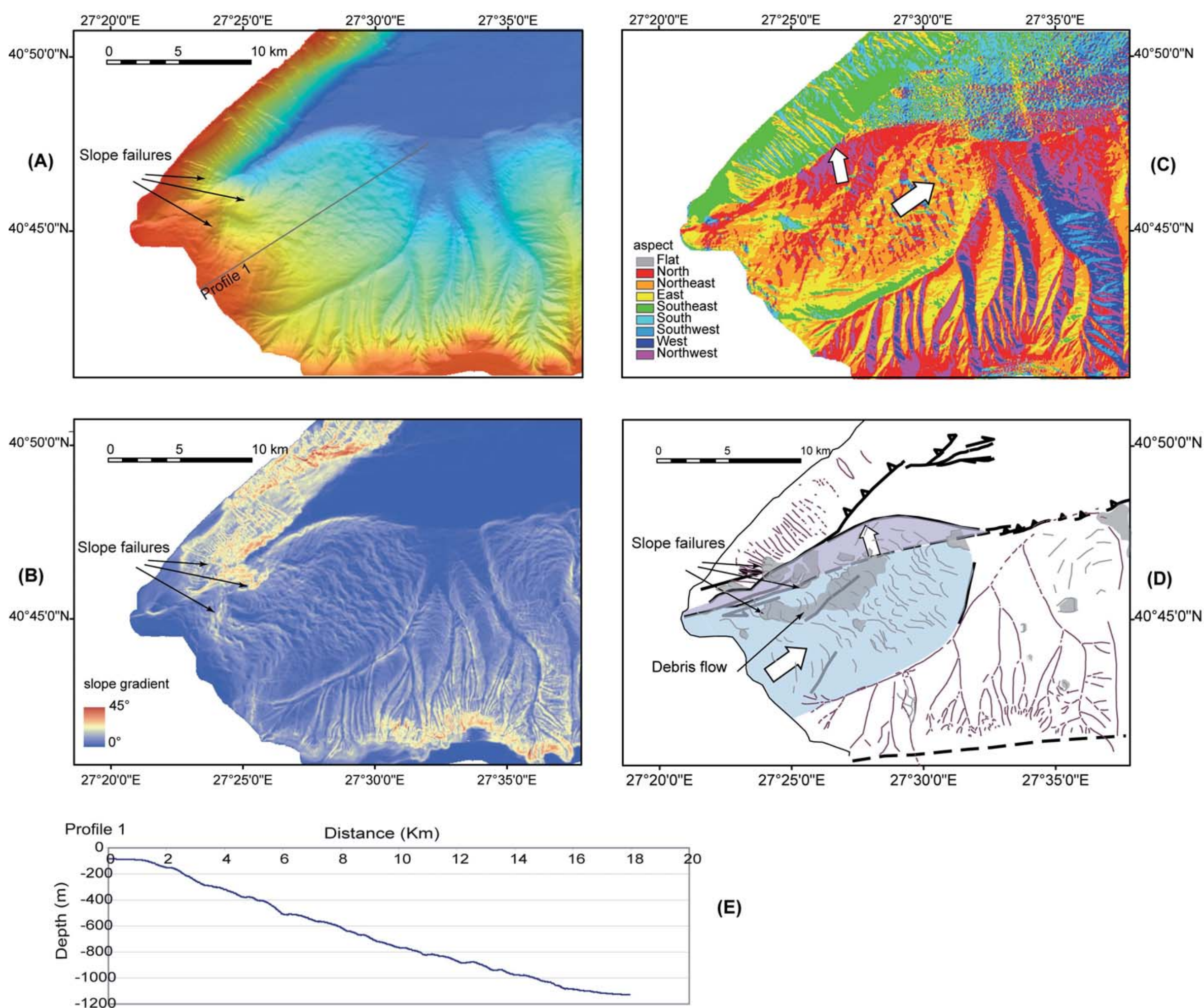

(E) 


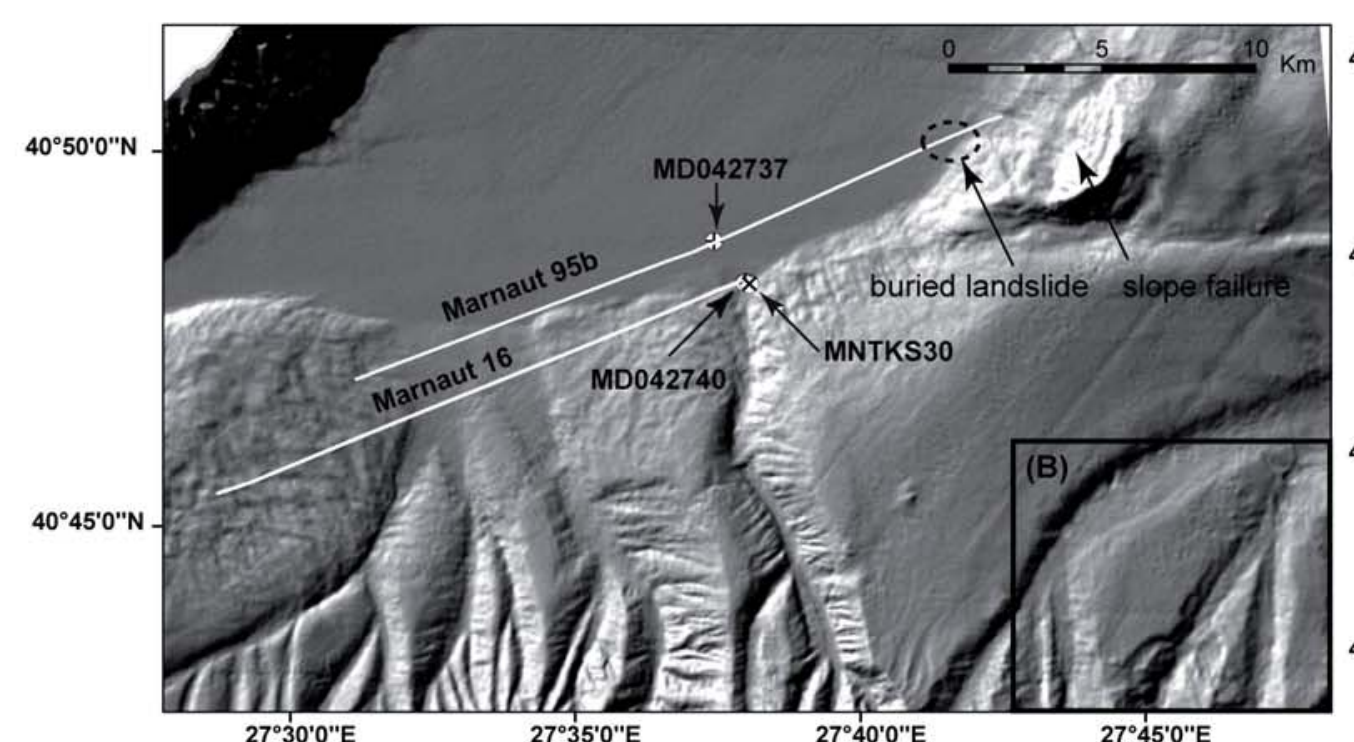

(A)
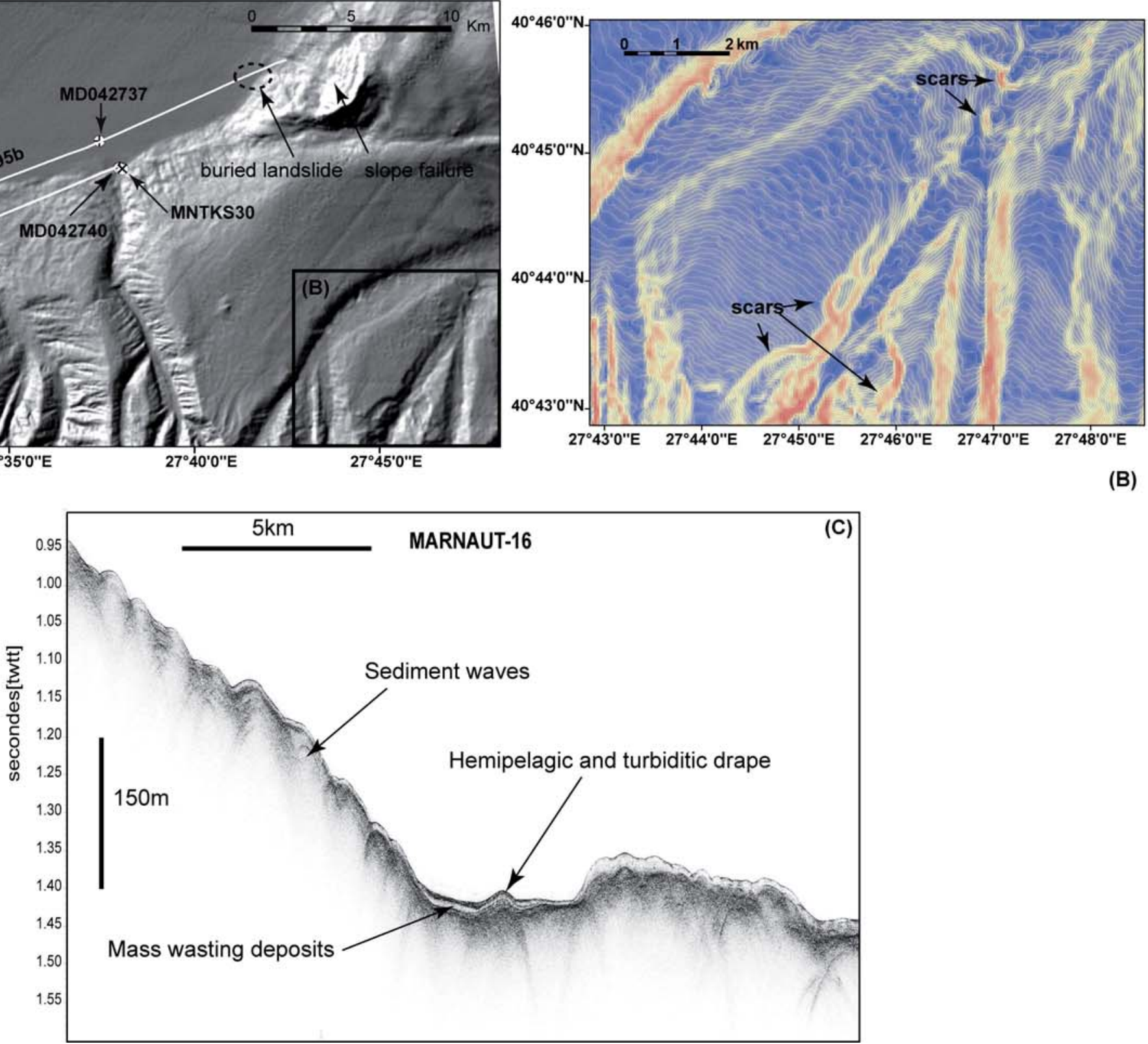

(B) 


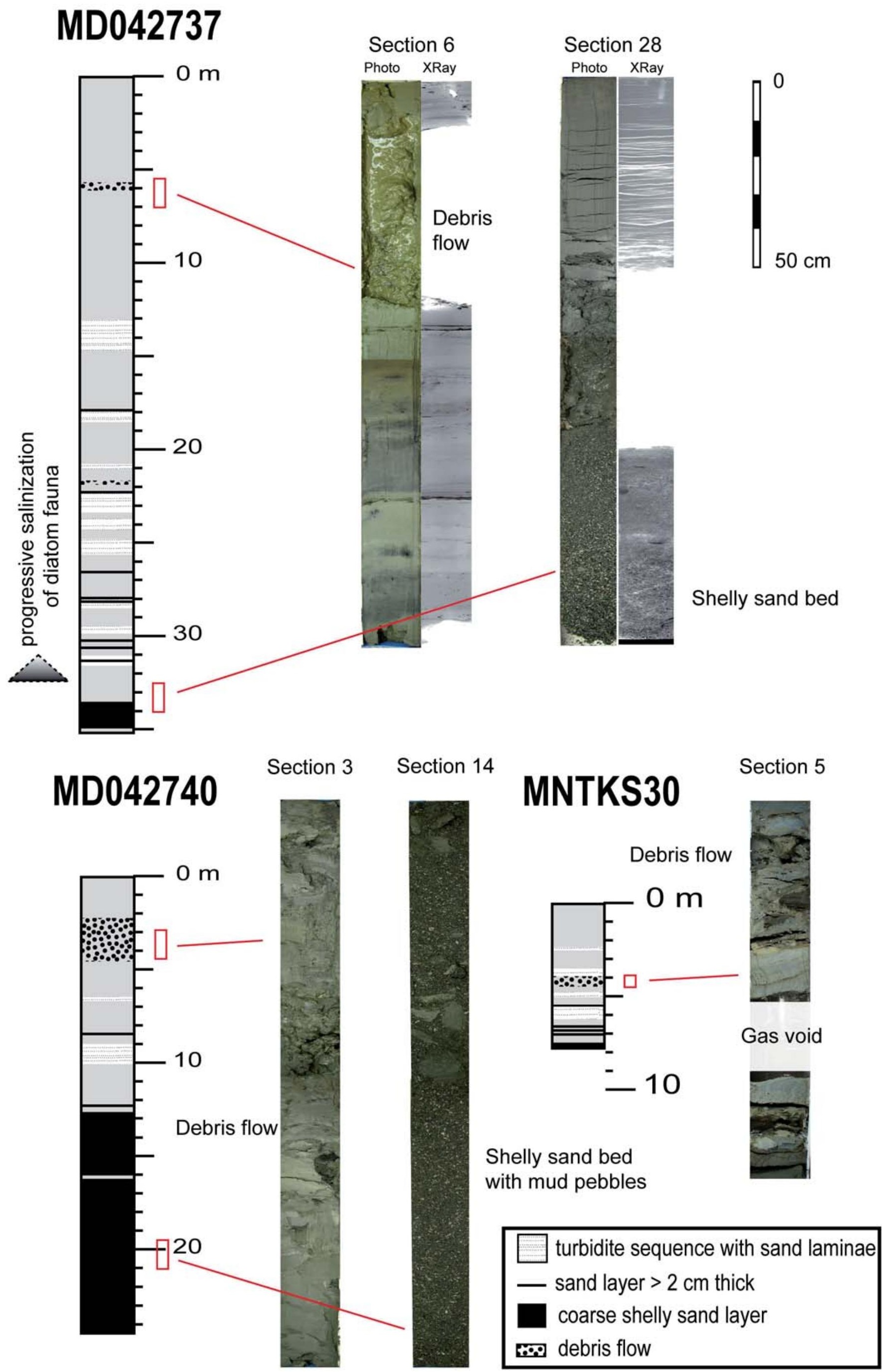




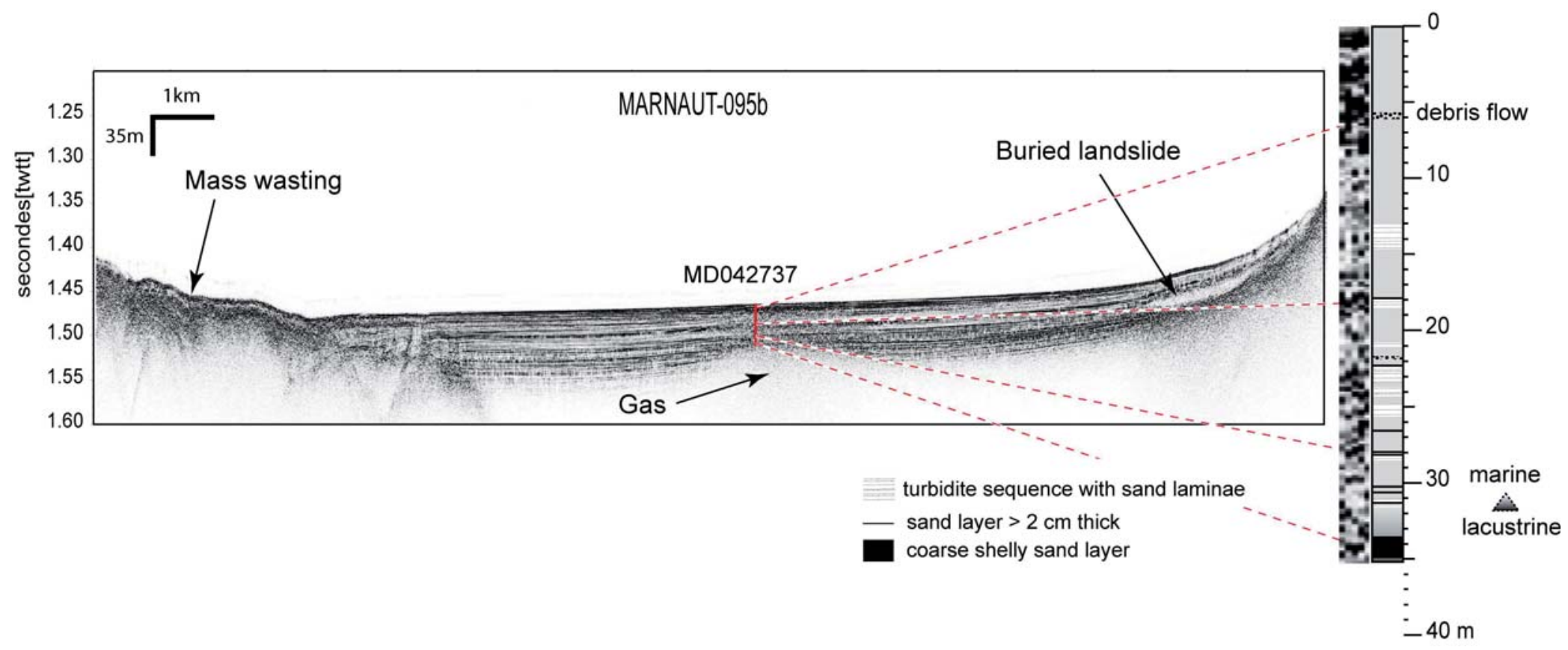




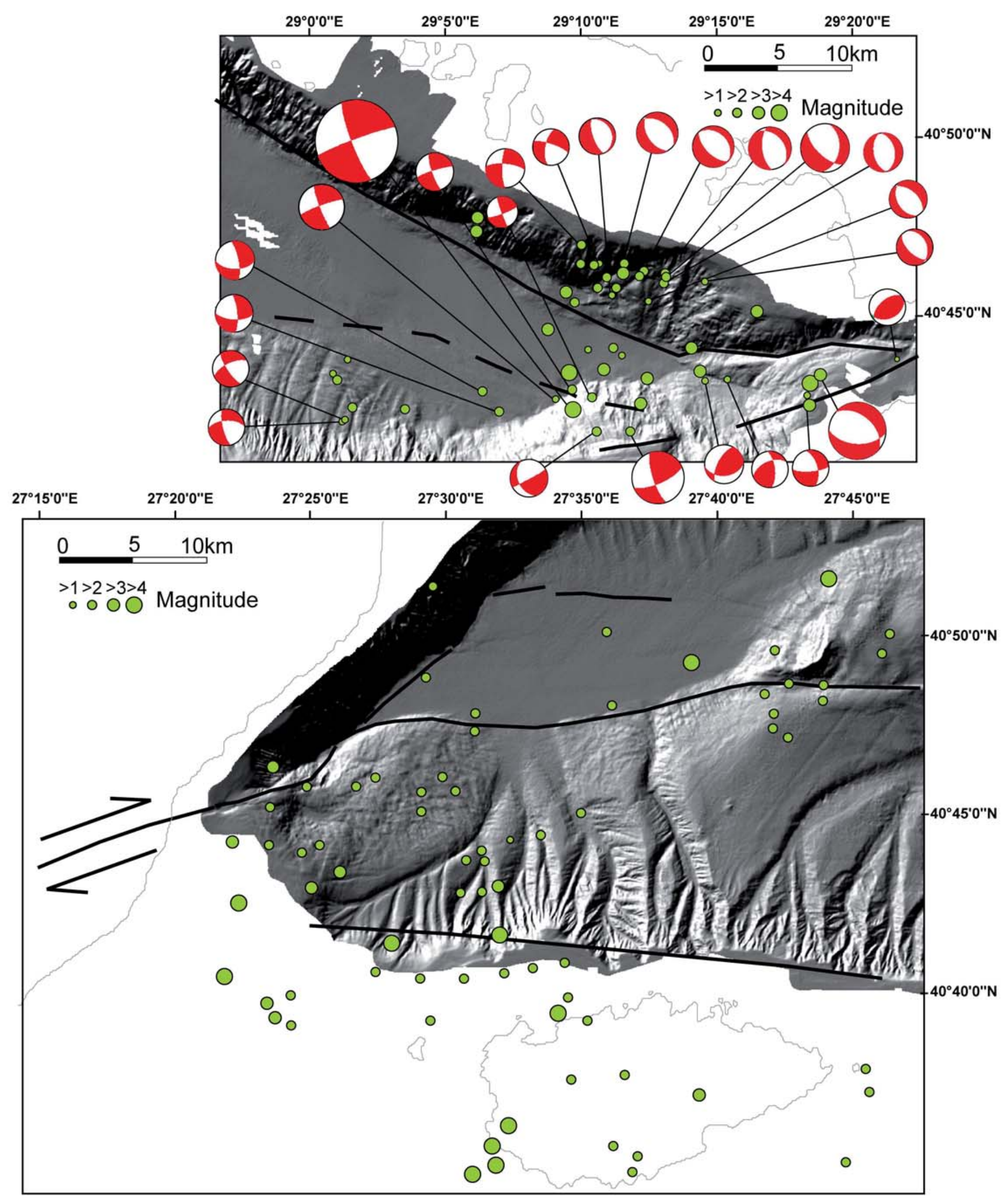

